\title{
EMPIRICKÝ VÝZKUM
}

\section{Kraje v České republice - existují souvislosti mezi ekonomickým rozvojem, sociálním kapitálem a výkonem krajských vlád?*}

\author{
TOMÁŠ KOSTELECKÝ, VĚRA PATOČKOVÁ, JANA VOBECKÁ** \\ Sociologický ústav AV ČR, v.v.i., Praha
}

\begin{abstract}
Regions in the Czech Republic - Are There Connections between Economic Development, Social Capital, and Government Performance?
\end{abstract}

\begin{abstract}
The article explores the connections between the performance of the Czech regional governments, the economic development of the regions, and the level of social capital in the regions. Analyses suggest that there is no relationship between regional government performance and the economic performance of the regions, and no relationship between regional government performance and the level of social capital in the regions. Government performance does not appear to be dependent on either of these two factors. Some positive statistical relationships do exist between the level of social capital and the economic performance of the regions. This relationship is stronger when the dynamics of the changes are evaluated - economic growth in the period between 1995 and 2004 was significantly higher in regions with a higher level of social capital. Analyses also revealed the strong effect of another factor - the level of human capital as measured by the education of the population - on all the other observed parameters of the regions. The regions with more educated inhabitants recorded more rapid economic growth, a higher level of social capital, and better performing governments.
\end{abstract}

Keywords: regional disparities, social capital, government performance, economic development, Czech Republic.

Sociologický časopis/Czech Sociological Review, 2007, Vol. 43, No. 5: 911-943

\section{Úvod}

Život lidí je a vždycky byl významně ovlivňován podmínkami v místě, kde žijí. První, čeho si pozorovatel zajímající se o teritoriální rozdíly obvykle všimne, jsou do očí bijící rozdíly v podmínkách života mezi jednotlivými zeměmi [Smith

\footnotetext{
* Výzkum byl proveden v rámci projektu „Vliv politické kultury, sociálně-ekonomických a institucionálních faktorů na rozdíly ve fungování českých regionů", který byl finančně podpořen Grantovou agenturou České republiky (grant č. 403/04/1300).

** Veškerou korespondenci posílejte na adresu: RNDr. Tomáš Kostelecký, CSc., Mgr. Věra Patočková, M. A., Mgr. Jana Vobecká, Sociologický ústav AV ČR, v.v.i., Jilská 1, 11000 Praha 1, e-mail: tomas.kostelecky@soc.cas.cz, vera.patockova@soc.cas.cz, jana.vobecka@soc. cas.cz.
} 
1776; World Development Indicators 2007] nebo mezi různými částmi globalizovaného světa [Wallerstein 1980; Daněk 2000; Jehlička et al. 2000]. Daleko méně zřejmá je skutečnost, že podstatné rozdíly je možné nalézt i mezi regiony v rámci jediného státu. Na regionální rozdíly, jejich příčiny, důsledky a očekávaný vývoj existuje celá řada vzájemně odlišných pohledů. Po dlouhou dobu se mělo za to, že regionální rozdíly v rámci jediného státu s fungující tržní ekonomikou budou postupně smazávány. ${ }^{1}$ Klasická ekonomická teorie předpokládala postupnou konvergenci v úrovni regionálního rozvoje v rámci jediné země [Barro, Sala-iMartin 1991]. Podobně i proces modernizace (zvláště industrializace a urbanizace jako jeho nedílné součásti) měl vést ke smazávání tradičních kulturních a sociálních rozdílů mezi regiony uvnitř jednoho státu. I vývoj institucí v posledních desetiletích vykazoval zjevné konvergenční tendence. Zhroucení komunistického systému a rozpad bipolárního světa ukončil po desetiletí trvající ideologický důvod k odlišné regionální politice i odlišnému vývoji regionů na obou stranách bývalé železné opony. Přímým důsledkem prohlubující se integrace evropského kontinentu byla nejen rostoucí míra unifikace legislativních norem, ale i institucí a organizačních struktur v členských zemích Evropské unie [Ardy, Gower 2002]. Ve snaze přiblížit se Evropské unii a zvýšit šanci na budoucí vstup do této organizace přibližovaly postupně své zákony a instituce evropským normám i země střední a východní Evropy [Gorzelak et al. 2001; Baldersheim et al. 2003; Kostelecký 2005; Illner 2006; Illner, Vajdová 2006].

Přes všechny teoretické předpoklady i řadu empiricky pozorovatelných tendencí $\mathrm{k}$ homogenizaci regionů se však ukázalo, že regionální rozdíly, jakkoliv vzniklé, mají stále neobyčejně silnou tendenci přetrvávat $\mathrm{v}$ čase. $\mathrm{K}$ obdobným závěrům dospěli vědci nejrůznějších oborů při studiu vývoje regionálních disparit v mnoha zemích, at́ už šlo o studium regionální ekonomiky [Langton, Morris 1986; Leonardi 1993] nebo studium sociálně-ekonomického vývoje [Koreleski 2005; Campo et al. 2006]. Významné rozdíly mezi regiony se ovšem netýkají jen sociálních nebo ekonomických struktur. Řada výzkumů zabývajících politickým chováním, politickou kulturou nebo sociálním kapitálem [Johnson et al. 1988; Brustein 1988; Taylor 1985; Krivý et al. 1996; Tworzecki 1996; Beugelsdijk, Schaik 2005; Zarycki 2000, 2007] potvrdila existenci významných rozdílů mezi regiony i v těchto oblastech. Konečně je v literatuře možno najít bezpočet dokladů o tom, že v rámci jediného státu mohou existovat i podstatné meziregionální rozdíly ve výkonu institucí [Leonardi, Nanetti 1990; Barrileaux et al. 1992; Putnam et al. 1993; Rice, Sumberg 1997; Cusack 1999; Martinusen 2004].

Ačkoliv je Česká republika zemí relativně malou, prostorově dobře integrovanou a národnostně v podstatě homogenní, studium nejrůznějších aspektů meziregionálních rozdílů ukázalo, že podstatné rozdíly mezi regiony existují

\footnotetext{
${ }^{1}$ Ve specifickém případě postkomunistických zemí toto tvrzení zcela neplatí, nebot' během přechodu od plánovaného hospodářství k tržnímu bylo možno očekávat vzrůst regionálních nerovností způsobených regionálně odlišným průběhem transformace případně znovuobjevením regionálních nerovností z období před obdobím komunismu, které byly plánovaným hospodářstvím potlačeny.
} 
v současné době i v naší zemi. Podobně jako v jiných zemích byly identifikovány významné regionální rozdíly jak v oblasti ekonomického rozvoje [Pavlínek 1997; Blažek, Csank 2007; Hampl 2007], tak u sociálně-ekonomických charakteristik regionů [Kostelecký 1995, 2002; Tomeš, Hampl 1999; Blažek 1999], politického chování [Kostelecký 1993, 2001], politické kultury [Vajdová, Kostelecký 1997], rozvoje občanské společnosti [Stachová 2005], sociálního kapitálu [Čermák et al. 2007] nebo výkonu regionálních institucí [Illner et al. 2007]. Zdá se, že existuje poměrně velké množství literatury, která se zaměřuje na zkoumání jednotlivých aspektů regionálních nerovností a jejich současný vývoj v České republice. Práce, které by se snažily hledat vzájemné souvislosti a vztahy, pokud jde o regionální nerovnosti v různých sledovaných oblastech (ekonomika, sociální struktura, politické chování, výkon institucí...), se však v české vědecké literatuře prakticky nevyskytujî. ${ }^{2}$ Pokusíme se existující mezeru zaplnit a podívat se na rozdíly mezi regiony v České republice poněkud obecnějším způsobem, než je obvyklé. Jako „regiony“ budeme chápat kraje v současném vymezení, protože jsou jedinou územní jednotkou mezi obcemi a státem, která má vlastní politické instituce, což nám umožní jejich výkon zařadit mezi sledované proměnné. Primárním cílem naší práce bude zjistit, jestli spolu meziregionální rozdíly v různých sledovaných oblastech vzájemně souvisí, eventuálně které spolu souvisí a jak těsně. Budeme si klást otázky typu: Dá se předpokládat, že kraje, které vykazují lepší ekonomickou výkonnost, budou mít zároveň lépe fungující krajské vlády? ${ }^{3}$ Korelují regionální rozdíly v ekonomické úrovni s regionálními rozdíly v úrovni sociálního kapitálu? Souvisí sociální kapitál v kraji s výkonem krajské vlády? Doufáme, že odhalení (ale i neodhalení) takových souvislostí na úrovni současných krajů v České republice může přispět $\mathrm{k}$ teoretické debatě o tom, jakými mechanismy regionální rozdíly vznikají, udržují se a (případně) zanikají, stejně tak jako k diskusím o vzájemných vztazích mezi fungováním regionálních vlád, ekonomiky a sociálním kapitálem v regionech a mechanismech jejich vzájemného ovlivňování.

\section{Ekonomický rozvoj, sociální kapitál, výkon vlád a jejich vzájemné souvislosti - teoretická diskuse}

Zkoumat, jak spolu vzájemně souvisí různé aspekty vývoje nějakého území, není nijak originální myšlenka. Ve skutečnosti jde o variaci na velmi staré téma společenských věd, ${ }^{4}$ které je přes své stáří stále aktuální. Již Adam Smith [1776] se

\footnotetext{
2 Práce Kosteleckého [Kostelecký 1995] se sice zabývala chováním obyvatel okresů a jejich podmíněnostmi ekonomickými a sociálními rozdíly mezi okresy na počátku 90 . let, byla však primárně zaměřená na zkoumání různých aspektů chování obyvatel - ekonomických, sociálních a politických - a vztahy mezi nimi.

3 Termín „krajské vlády“ v tomto článku chápeme jako ekvivalent anglického termínu "regional governments", který označuje volené i nevolené orgány na regionální úrovni.

${ }^{4} \mathrm{~V}$ tomto textu se úmyslně nebudeme zabývat vztahem mezi geografickými podmínkami a společenským rozvojem, který je velkým tématem geografie, tradičně stojícím na pomezí
} 
snažil ve své práci odhalit příčiny toho, proč jsou některé národy bohatší než jiné, přičemž dospěl k názoru, že bohatství není předurčeno odlišnostmi ve vnějších podmínkách. Karel Marx [1867] se pokoušel vysvětlit společenské rozdíly mezi zeměmi jako odraz rozdílů ve způsobu organizace a fungování ekonomiky. Max Weber [1904-1905] naopak viděl kulturní a náboženské odlišnosti mezi rưznými společnostmi jako prvotní př́činu jejich odlišného ekonomického vývoje. Lipset [1960] a Dahl [1989] každý jiným způsobem dospěli k tvrzení, že formy vlády jsou v různých zemích primárně ovlivněny stupněm jejich socio-ekonomického rozvoje. Tocqueville [1835] nebo Almond a Verba [Almond, Verba 1963] naopak vysvětlovali rozdíly ve fungování institucí socio-kulturními odlišnostmi. Granato, Inglehart a Leblang [Granato, Inglehart, Leblang 1996] testovali vliv kulturních odlišností na ekonomický vývoj zemí a dospěli k závěru, že rozdíly v kulturních hodnotách ekonomiku významně ovlivňují. Podobně i Harisson a Huntington [2000] zdůrazňují význam kulturních rozdílů mezi zeměmi na jejich ekonomickou výkonnost.

Již na krátkém výčtu známých prací, zabývajících se souvislostmi mezi různými aspekty vývoje společností, je možné si uvědomit tři různé věci. Předně je zřejmé, že ačkoliv je výčet studovaných konkrétních témat velmi dlouhý, je možné je přiřadit $\mathrm{k}$ několika málo obecným kategoriím, jako jsou ekonomický rozvoj, sociální a kulturní vývoj, struktura a výkon institucí. Druhým rysem zmíněných prací je to, že analýza souvislostí mezi jednotlivými oblastmi vývoje společnosti má prakticky vždycky podobu hledání kauzálních vztahů, při nichž je vývoj v některé oblasti považován za závisle proměnnou a vývoj v jiné oblasti za nezávisle proměnnou. Typické je ovšem, že nepanuje shoda na směru kauzality. Jinými slovy: jednotliví autoři se liší v tom, co považují za př́íčiny rozdílů a co považují za jejich následek. Konečně si lze povšimnout, že z hlediska teritoriálního jsou jednotkou sledování nejčastěji celé státy a pozornost výzkumníků je zpravidla zaměřena na zkoumání rozdílů mezi nimi.

Vzhledem k zaměření našeho vlastního výzkumu na rozdíly mezi ekonomickým rozvojem, sociálním kapitálem a výkonem krajských vlád v současné České republice bude lépe, když se v další části tohoto oddílu omezíme jen na diskusi prací zaměřených na studium různých aspektů nerovností mezi regiony ${ }^{5}$

společenských a přírodních věd [Hampl 1971]. Upozorňujeme jenom, že i v rámci geografické teorie existuje celá škála různých názorů na to, jak významný vliv má na společnost vnější prostředí. Příkladem odlišných přístupư může být například geografický determinismus vycházející ve své čisté formě [např. Ratzel 1897] z představy, že ekonomický, sociální a kulturní rozvoj společnosti je předurčen nezměnitelnými a lidskou společností neovlivnitelnými geografickými faktory, jako jsou např́íklad podnebí, vzdálenost od moře, úrodnost půdy nebo nerovnoměrné rozmístění nalezišt́ nerostných surovin a zdrojů energie. Na druhou stranu existuje řada geografů, kteří zdůrazňují význam „endogenních vlivừ spočívajících například v mobilizaci regionálně specifických aktérů a jejich sítí pro rozvoj regionů [pro podrobnou diskusi těchto přístupů viz Blažek, Uhlíř 2002].

${ }^{5}$ Kromě prací zaměřených na regionální úroveň existuje i omezené množství literatury zabývající se vztahy mezi sociálním kapitálem, ekonomickým rozvojem a výkonem vlád 
a jejich vzájemných souvislostí. Toto rozhodnutí má nejenom praktickou výhodu v tom, že radikálně zúží okruh sledované literatury, ale umožní nám pominout jednu z možných příčin teritoriálních rozdílů v úrovni ekonomického rozvoje, sociálního kapitálu i fungování vlád, totiž odlišnosti v samotné struktuře institucí [Ostrom 1990]. Zatímco na úrovni jednotlivých států mohou být odlišnosti ve struktuře institucí velmi významné, což je může činit klíčovým faktorem vysvětlujícím všechny další nalezené rozdíly, ${ }^{6}$ institucionální design regionálních vlád ${ }^{7}$ je zpravidla $z$ větší části předepsán zákony dané země, což jej do značné míry unifikuje a z hlediska analýzy vzájemných souvislostí mezi ekonomickým rozvojem, sociálním kapitálem a výkonem regionálních vlád tak dělá z další potenciálně významné nezávisle proměnné proměnnou ,kontrolovanou“.

Ačkoliv mají práce zabývající se vlivem různých „neekonomických faktorů" na regionální rozvoj relativně dlouhou tradici [Myrdal 1957; Granovetter 1973], skutečný boom zájmu o ně nastal až po publikaci slavné knihy Making Democracy Work [Putnam et al. 1993], ve které byly shrnuty výsledky dlouholetých výzkumů fungování regionálních vlád v Itálii. Autoři sami uvádějí [op. cit.: 15], že jejich primárním cílem bylo zkoumat původ efektivní vlády. Vytvořili proto agregátní index výkonu vlády, ${ }^{8}$ který jim v jejich úvahách sloužil jako závisle proměnná, jejíž regionální variabilitu se snažili vysvětlit. Nezávisle proměnných použili celou řadu: populační velikost regionu, ideologickou polarizaci a fragmentaci stranického systému v regionech, míru konsenzu voličů i regionálních elit ohledně klíčových sociálních a ekonomických otázek, rozdíly v počtu ekonomických konfliktů, teritoriální ekonomické a demografické disparity uvnitř

na lokální úrovni nebo na úrovni jediného regionu [např. Cusack 1999; Kaufman, Tepper 1999; Martinussen 2004; Coffé, Geys 2005; Myant, Smith 2006]. Vzhledem k problémům se získáváním dat na lokální úrovni je však v těchto studiích odlišně operacionalizována většina sledovaných proměnných, což zmenšuje jejich srovnatelnost se studiemi zabývajícími se regiony.

${ }^{6}$ Srovnej například vliv odlišného institucionálního uspořádání na extrémně odlišný vývoj původně ekonomicky a kulturně relativně homogenních států, jako jsou KLDR a Jižní Korea, nebo byly Spolková republika Německo a Německá demokratická republika.

7 Na tomto místě je třeba upozornit na skutečnost, že samotné regiony, které jsou spravovány regionálními vládami, mají v různých zemích podobu různě velkých územních jednotek. Skála velikostí regionů je velmi široká: za regionální vlády jsou považovány vlády jednotlivých států USA nebo Indie s miliony až desítky milionů obyvatel, krajů v České republice s počtem obyvatel v rozmezí statisíců až jednoho milionu, stejně jako třeba regionů v Dánsku, jejichž populační velikost se pohybuje mezi desítkami a stovkami tisíc obyvatel. Velikost regionů samozřejmě může ovlivňovat i kompetence a strukturu regionálních vlád.

${ }^{8}$ Index výkonu vlády byl agregátem dvanácti ukazatelů výkonu zahrnujících stabilitu regionálních vlád, včasnost přijímání regionálních rozpočtů, rozvinutost statistických a informačních služeb, kvalitu reformní legislativy, inovativnost legislativy, rozšíření center pro předškolní děti, využití moderních instrumenti̊ průmyslové politiky, investic do zemědělství, investic do zdravotnictví, investic do bydlení a experimentálně měřené úrovně komunikace regionální vlády s občany. 
zkoumaných regionů, sociální stabilitu regionů, míru vzdělanosti obyvatel zkoumaných regionů, míru urbanizace, personální stabilitu v institucích regionálních vlád, politickou sílu Italské komunistické strany v regionech, míru socio-ekonomické modernity ${ }^{9}$ regionů a míru občanskosti ${ }^{10} \mathrm{v}$ regionech. Jenom poslední tři jmenované nezávisle proměnné se ukázaly jako pozitivně korelované s indexem výkonu vlád, přičemž jen u dvou posledních byla korelace silná a její interpretace jasná. ${ }^{11}$ Výkon italských regionálních vlád byl tím vyšší, čím byl region ekonomicky modernější, a čím větší míru občanskosti vykazoval. Nejzajímavější bylo ovšem tvrzení autorů, že míra občanskosti italských regionů není jenom jedním $\mathrm{z}$,vedlejších efektů“ jejich ekonomického rozvoje, ale že je vztah kauzality mezi těmito dvěma proměnnými opačný. ${ }^{12}$ Důležité bylo rovněž to, že Putnam při své snaze zkoumat prŕćčiny rozdílů v míre občanskosti italských regionů spojil, s odkazem na Colemana [Coleman 1988] koncept občanskosti s konceptem „,sociálního kapitálu“, který definoval jako „rysy sociální organizace jako důvěra, normy a sítě, které mohou zlepšit efektivitu fungování společnosti usnadňováním koordinovaných akcí“ [Putnam et al. 1993: 167]. Hypotézy generované analýzou italských dat následně Putnam testoval na datech z USA. Výsledky [Putnam 1995, 2000] se zdály potvrzovat jeho klíčovou tezi o mimořádném významu sociálního kapitálu jako faktoru ovlivňujícího jak ekonomický rozvoj, tak výkon vlád.

Putnamova práce měla obrovský ohlas. Kritické ohlasy byly několika různých typů. Někteří vědci kritizovali samotné závěry vyvozené ze shromážděných dat a nabízeli alternativní interpretace pro nalezené statistické souvislosti, případně vznášeli pochybnosti o tom, zda Putnamem proklamovaný směr kauzální souvislosti mezi sociálním kapitálem, ekonomickým rozvojem a výkonem

\footnotetext{
${ }^{9}$ Míra ekonomické modernity byla agregátem založeným na následujících ukazatelích: př́ijem na obyvatele, regionální HDP, podíl zaměstnaných v zemědělství, podíl zaměstnaných $\mathrm{v}$ prưmyslu, podíl zemědělské produkce na přidané hodnotě a podíl průmyslové produkce na celkové přidané hodnotě.

${ }_{10}$ Index občanskosti byl agregátem čtyř ukazatelů: pozitivně koreloval s počtem sportovních a kulturních asociací $\mathrm{v}$ přepočtu na obyvatele, s účastí v referendech a čteností novin, negativně koreloval s využitím preferenčních hlasů, které autoři považovali $\mathrm{v}$ italských podmínkách za indikátor rozšíření klientelismu.

${ }_{11}$ Autoři připouštějí, že s rostoucí silou a větším zastoupení politiků Komunistické strany Itálie v regionální vládě roste její výkon, tuto skutečnost však nijak podrobněji nevysvětlují s odůvodněním, že všechny prŕípady participace komunistů na moci byly zaznamenány v regionech s největší mírou občanskosti. Není tedy jasné, zda přítomnost komunistů v regionální vládě sama o sobě zvyšovala její výkon, nebo naopak větší občanskost regionů vedla $\mathrm{k}$ většímu zastoupení komunistů v regionální vládě [Putnam et al. 1993: 119].

${ }_{12}$ Vzhledem $\mathrm{k}$ tomu, že autoři měli $\mathrm{k}$ dispozici relativně dlouhou časovou řadu indikátorů, které měřily jak ekonomickou výkonnost, tak úroveň sociálního kapitálu a výkon regionálních vlád, mohli testovat sílu vztahu mezi např́íklad ekonomickým rozvojem v na počátku 20. století a úrovní občanskosti v 70. letech a zároveň úrovní občanskosti na počátku 20. století a ekonomickým rozvojem v 70. letech, nebo úrovní občanskosti v 70. letech a výkonem vlád $\mathrm{v} 80$. letech atd. Tento př́stup měl tu podstatnou výhodu, že bylo možno odlišit potenciální prúíčinu od potencionálního následku - příčina totiž musí vždy časově předcházet následku.
} 
vlád odpovídá realitě. Portes a Landolt [Portes, Landolt 2000] kupříkladu tvrdili, že všechny nalezené rozdíly mezi italským severem a jihem jsou ve skutečnosti odrazem odlišné míry integrace italského jihu se zbytkem dnešní Itálie. Tarrow [1996] kritizoval Putnama za ignorování role, jakou hrály při potlačování svobodného sdružování a důvěry na italském jihu samotné tamní vlády, a zpochybňoval tak směr kauzality od sociálního kapitálu směrem k výkonu vlád. Podobně i Portes [2000] považoval sociální kapitál a výkon vlád za vzájemně propojené a obě shodně podmíněné úrovní materiální prosperity a strukturou institucí. Rozdíly ve fungování institucí považovali za klíčovou př́čcinu všech ostatních zjištěných regionálních nerovností i Paxton [2006] a McLaren a Baird [McLaren, Baird 2006]. Putzel [1997] připomněl, že v italských regionech, jimž Putnam přisuzoval vysokou úroveň sociálního kapitálu, se na jeho produkci podílely i další organizace a instituce než jenom ty, kterými se ve svých analýzách zabýval Putnam. Boix a Posner [Boix, Posner 1998] měli za to, že při zkoumání vztahů mezi ekonomickým rozvojem, sociálním kapitálem a výkonem vlád nemá smysl hledat „příčinu“ a "následek“. Sledované kategorie jsou podle nich vzájemně rovnocenné a jejich vztahy mají charakter "sociálního ekvilibria“, v němž se jednotlivé prvky vzájemně ovlivňují formou pozitivních či negativních zpětných vazeb. V rưzných regionech se ustálí různá ekvilibria - úspěšné regiony jsou typické zároveň vysokou úrovní sociálního kapitálu, vysokou ekonomickou úrovní i vysokým výkonem vlád, zatímco neúspěšným regionům je vlastní kombinace špatného výkonu vlády, nízké ekonomické úrovně i nízké hodnoty sociálnúho kapitálu. Jakmile se jednou ekvilibrium ustaví, je obtížné přejít z jednoho stavu do jiného, nebot́ proti dlouhodobé změně jednoho z prvků ekvilibria působí vzájemné vazby na ostatní prvky ekvilibria. ${ }^{13}$ Boix a Posner nicméně připouští, že nejdůležitější ze tří prvků ekvilibria je sociální kapitál, nikoliv ovšem proto, že by byl z kauzálního pohledu přičinou vývoje v ostatních oblastech, ale proto, že ho lze nejméně snadno změnit. Základní příčinu toho, proč je v některých regionech nižší úroveň sociálního kapitálu než v jiných, však spatřovali v hloubce sociálních nerovností, které brání svobodné kooperaci a důvěře coby nezbytným předpokladům úspěšného budování sociálního kapitálu.

Jiní Putnamovi oponenti nepolemizovali s jeho interpretacemi, ale zaměřili se na kritiku konceptů, které použival a jejich vhodnost při studiu tématu, kterým se zabýval. Edwards a Foley [Edwards, Foley 1998] kritizovali automatický

${ }^{13}$ Jestliže kupř́íkladu v úspěšném regionu dojde $\mathrm{z}$ nějakých vnějších př́ičin k ekonomickým problémům, vysoká úroveň sociálního kapitálu a dobrý výkon vlády pomůže ke zlepšení ekonomické situace. Podobně úspěšný region s vysokou úrovní sociálního kapitálu a dobrou ekonomickou situací snáze "přečká“ i špatný výkon vlády (a pravděpodobně po čase dojde ke zlepšení výkonu vlády nebo její výměně za vládu s lepším výkonem). V neúspěšném regionu naopak nemusí pomoci ke zlepšení ekonomické situace ani investice $z$ vnějších zdrojů, nebot' díky špatnému výkonu vlády a nízké úrovni sociálního kapitálu nebudou mít očekávané účinky na ekonomickou situaci. Podobně nastoupí-li do úřadu výkonnější vláda, nemusí se jí podařit zlepšit ani ekonomickou situaci, ani zvýšit úroveň sociálního kapitálu a její výkon naopak může postupně klesnout na „standardně nízkou“ úroveň. 
předpoklad, že sociální kapitál je něco, co přispívá k ekonomickému rozvoji. Připomínali názor ekonoma Mancura Olsona [Olson 1982], který považoval jeden z Putnamem používaných indikátorů sociálního kapitálu - hustotu sítí dobrovolných sdružení - za překážku efektivního fungování trhu, protože účastníci takových sítí využívají svoji sílu spíše k hledání ekonomicky neoprávněných výhod než pro společné dobro. Halpern [2005] upozornil na to, že je nutno rozlišovat sociální kapitál „uvnitř skupin“, jehož vysoká hladina nemusí být ku prospěchu lidí stojících mimo dané skupiny, od sociálního kapitálu "mezi skupinami“, který jedině se dá považovat za veřejný statek v pravém slova smyslu. ${ }^{14}$ Podle Hadjimichilise [Hadjimichilis 2007] jsou sociální sítě často postaveny na nerovných vztazích zúčastněných, a proto $\mathrm{v}$ nich nemají užitek ze vzájemných interakcí všichni, ale jen ti, kdo mají větší moc. Připomíná rovněž kontrast Putnamova chápání sociálního kapitálu jako veřejného statku a sociálního kapitálu v pojetí Bourdieua [Bourdieu 1986], pro nějž byl sociální kapitál individuálním zdrojem použitelným jedincem $v$ soutěži s jinými.

Někteří kritikové věnovali pozornost operacionalizaci základních konceptů. Edwards a Foley [Edwards, Foley 1998] upozornili na to, že Putnam ve svých pozdějších pracích (a také řada jeho následovníků) stále častěji operacionalizoval sociální kapitál s pomocí dat o důvěře, aktivitě v dobrovolných sdruženích a normách reciprocity získaných ze sociologických výzkumů provedených na reprezentativním vzorku populace studovaných území. Tím koncept, který je ze své podstaty "relační", tj. vztahuje se k interakci a vzájemným vztahům mezi lidmi, ztrácí část svých schopností popsat „kontextovou specifičnost" interakcí. Stává se tak pouhým dalším indikátorem z řady individuálních znaků jednotlivců, které není možné agregovat za určitou územní jednotku, a vzniklý statistický agregát (zpravidla průměr) nelze považovat za dobrý ukazatel úrovně sociálního kapitálu daného území. V podobném duchu argumentovali i Paxton [1998] nebo Mohan a Mohan [Mohan, Mohan 2002]. Lemann [1996] upozornil na to, že Putnamova operacionalizace sociálního kapitálu zcela pomíjí nové formy participace na kolektivních aktivitách, které jsou méně závislé na fyzickém kontaktu, než tomu bylo dříve. Zcela z jiného úhlu pohledu kritizovali Putnamův způsob operacionalizace sociálního kapitálu například Hospers a van Lochem [Hospers, van Lochem 2002], kteří tvrdili, že generalizovaná důvěra coby jedna ze základních součástí sociálního kapitálu vyrůstá z příležitostí lidí svobodně se potkávat a komunikovat s cizími lidmi, nikoliv komunikací se známými lidmi v rámci organizovaných sdružení. V duchu tradice Jane Jacobs [1961] a Jürgena Habermase [Habermas 1989] zdůrazňujících význam neformálních a neorganizovaných interakcí mezi lidmi pro posílení politické participace pak navrhovali měřit úroveň sociálního kapitálu například relativní hustotou veřejně přístupných míst vhodných pro setkávání (parky, kulturní centra, kina, divadla...) a nikoliv „institucionální hustotou“ dobrovolných sdružení.

\footnotetext{
${ }^{14}$ Na tyto oprávněné výtky ve svých pozdějších pracích Putnam reagoval rozlišením sociálního kapitálu na dva typy: „bonding“ a „bridging“.
} 
Navzdory řadě kritiků se našel velký počet vědců, kteří Putnamovu práci považovali za zajímavou hypotézu, kterou stojí za to testovat. Výsledky takových testů byly rozporuplné. Leonardi [1993] ve své studii potvrdil závislost ekonomického rozvoje na úrovni sociálního kapitálu v italském regionu Mezzogiorno. Helliwell a Putnam [Helliwell, Putnam 1995, 2000] dospěli ke stejným závěrům na úrovni celé Itálie. Studie OECD [2001] poukázala na pozitivní vliv sociálního kapitálu na ekonomický rozvoj vybraných regionů. Studie Schneidera et al. [Schneider et al. 2000] také potvrdila pozitivní vliv intenzity sociální komunikace na ekonomický růst $\mathrm{v}$ regionech $\mathrm{EU}$, ačkoliv autoři upozornili, že $\mathrm{v}$ jejich modelech ekonomického růstu zůstaly nejsilnějšími nezávisle proměnnými jiné (ekonomické) faktory. Rice a Sumberg [Rice, Sumberg 1997] testovali hypotézu o vztahu mezi indexem občanské kultury a indexem výkonu vlády na úrovni amerických států. Výsledkem jejich práce bylo potvrzení pozitivní korelace mezi oběma ukazateli, ačkoliv vztah nebyl tak těsný, jako tomu bylo v případě regionů v Itálii. K poněkud jiným závěrům dospěl o několik let později př̀i studiu amerických států Knack [2002]. Ten rozlišil aspekty sociálního kapitálu popisující generalizovanou reciprocitu (důvěra, dobrovolnická aktivita, participace ve sčítání lidu) od aspektů popisujících budování sítí ve společnosti (aktivity v dobrovolných sdruženích a udržování neformálních kontaktů). Zatímco prvně zmíněný typ indikátorů vykazoval pozitivní korelaci s výkonem vlády, druhý typ ukazatelů s výkonem vlády nijak nesouvisel. Konečně Casey a Christ [Casey, Christ 2005] zjistili, že pokud bereme v úvahu vliv rozdílností v úrovni lidském kapitálu (měřeném vzděláním populace), neexistuje v USA žádný vztah mezi úrovní sociálního kapitálu jednotlivých států a ekonomickými charakteristikami, jako je růst HDP nebo míra nezaměstnanosti, ale existuje negativní korelace mezi hladinou sociálního kapitálu a ekonomickou nerovností, protože ve státech Unie s větší úrovní sociálního kapitálu jsou menší ekonomické nerovnosti a naopak.

Jestliže byly Putnamovy hypotézy testovány mimo země, jejichž analýza k jejich formulování vedla, závěry byly ještě rozporuplnější. Výsledky z některých zemí hypotézy potvrzovaly. Kupříkladu Callois [2006] prokázal silný pozitivní vliv sociálního kapitálu na ekonomickou výkonnost rurálních regionů ve Francii, čímž zopakoval v konkrétnější podobě obecné závěry Levyho [Levy 1999]. Mayer [2001] našel jasnou pozitivní korelaci mezi úrovní sociálního kapitálu a výkonem regionálních vlád $\mathrm{v}$ Indii. $\mathrm{K}$ tomu ovšem dodával, že větší vliv na regionální rozdíly mají odlišnosti ve vzdělanosti obyvatel. V jiných zemích badatelé nedospěli k jednotnému závěru. Kupř́kladu Hall [1999] zjistil, že v Británii dvě ze tří hlavních dimenzí sociálního kapitálu - participace v sítích dobrovolných sdružení a důvěra - zdaleka tolik nekorelují, jak se předpokládá, takže je problematické je jednoduše agregovat do indexů sociálního kapitálu, protože hodnoty agregátních ukazatelů budou podstatně záviset na váze, jaká se přisoudí oběma měřeným dimenzím. Hall navíc tvrdil, že sociální kapitál nemůže být automaticky považován za nezávisle proměnnou, která svým působením ovlivňuje výkon vlád, ale že naopak vlády svým pưsobením mohou hrát a také hrají významnou roli při posilování sociálního kapitálu v nějakém území. Casey [2004] zjistil, že 
zatímco některé indikátory úrovně sociálního kapitálu (důvěra a hustota občanských sdružení) jsou pozitivně korelovány s ekonomickým rozvojem britských regionů, jiné ukazatele (hustota ekonomických asociací) jsou s ekonomickým rozvojem naopak korelovány negativně. Podobně rozporuplné byly také závěry Reillyho a Phillpota [Reilly, Phillpot 2002], kteř́i studovali vztahy mezi ekonomickou výkonností, sociálním kapitálem a výkonem regionálních vlád ve státě Papua - Nová Guinea, jedné z mála chudých zemí, která je již relativně dlouhou dobu demokratická a kde se vlády střídají na základě výsledků voleb. Nezjistili žádný vztah mezi stupněm ekonomického rozvoje a výkonem regionálních vlád, potvrdili ovšem pozitivní vztah mezi některými dílčími mírami sociálního kapitálu (poslechovost rádia, čtenost novin, zastoupení žen v politice) a úrovní ekonomického rozvoje regionů. Nespokojenost s výsledky vedla autory ke hledání dalších potenciálně významných nezávisle proměnných. Výsledkem jejich analýzy bylo zjištění, že klíčovým faktorem je etnická diverzita - v regionech s vysokou etnickou diverzitou byla zjištěna nižší úroveň sociálního kapitálu, horší výkon vlád i nižší stupeň ekonomického rozvoje.

Konečně výsledky některých studií předpokladům vycházejících z Putnama zcela protiřečily. Studie o regionálním rozvoji periferních regionů v kanadském Quebecu [Polèse, Shearmur 2006], jasně ukázala, že k ekonomickému poklesu v těchto regionech dochází navzdory tomu, že vykazují vysokou hladinu sociálního kapitálu. Na základě výsledků studie se sice nedalo vyloučit, že nějaká forma pozitivního vlivu sociálního kapitálu na ekonomiku existuje, v konkrétně zkoumaných regionech se však mohlo v praxi jednat přinejlepším o zmírňování efektu ekonomického úpadku, který je podle autorů nevyhnutelným důsledkem poklesu porodnosti a periferní polohy. Studie Milnera a Erssona [Milner, Ersson 2000] zaměřená na regiony ve Śvédsku přišla dokonce se závěrem, že lze prokázat silnou negativní korelaci mezi úrovní sociálního kapitálu a ekonomickým rozvojem, což autoři opět přičítali silnému vlivu geografických faktorů projevujících se v polarizaci Švédska na urbánní ekonomicky výkonný jih s relativně nižší hladinou sociálního kapitálu a periferní rurální ekonomicky zaostávající sever s relativně vyšší hladinou sociálního kapitálu. Podobně studie Buttricka a Morana [Buttrick, Moran 2005] zaměřená na analýzu faktorů ekonomického úspěchu regionů v Rusku skončila závěrem, že vztah mezi úrovní sociálního kapitálu a ekonomickým rozvojem je negativní. V jihoruských regionech typických nejvyššími hodnotami sociálního kapitálu byl zaznamenán nejmenší ekonomický růst a nejvyšší nezaměstnanost.

\section{Ekonomický rozvoj, sociální kapitál a výkon vlád - kraje v České republice}

Poučeni výsledky analýz zaměřených na zkoumání vztahu mezi ekonomickým rozvojem, sociálním kapitálem a výkonem vlád na regionální úrovni v jiných zemích, pokusíme se o hledání podobných vztahů a souvislostí v českém kontextu. Z literatury je zřejmé, že výsledky analýz přinejmenším částečně závisí 
na tom, jak jsou operacionalizovány proměnné, mezi nimiž jsou hledány vztahy. Obecně je možné bud' pracovat s malým počtem agregovaných proměnných popisujících ve velmi obecné podobě ekonomický rozvoj, sociální kapitál a výkon regionálních vlád, nebo zkoumat vztahy mezi velkým počtem jednotlivých dílčích ukazatelů. V prvním př́padě se výsledky dobře interpretují (např. „V regionech s vyšším sociálním kapitálem byl zaznamenán rychlejší ekonomický rozvoj“), ale zároveň jsou v praxi dosti závislé na tom, které dílčí ukazatele se pro zkonstruování konkrétních agregátních ukazatelů použijí. Výsledkem analýzy je často nenalezení žádných statisticky významných souvislostí. ${ }^{15}$ Ve druhém př́ipadě se zvětšuje pravděpodobnost, že budou nalezeny statisticky významné souvislosti, ale výsledky se obvykle hưře interpretují (např. „počet sportovních a kulturních sdružení na 1000 obyvatel pozitivně koreluje s HDP regionu a zároveň procento dobrovolných dárcủ krve negativně koreluje s nákladností výkonu krajské vlá$\left.d y^{\prime \prime}\right)$. V našem případě jsme se rozhodli pracovat s agregátními ukazateli, nebot' nám jde primárně o postižení vztahů mezi obecnými kategoriemi, nikoliv o hledání statistických souvislostí mezi jednotlivými proměnnými. V zásadě se soustředíme pouze na zkoumání vztahů mezi třemi základními obecnými proměnnými charakterizujícími úroveň ekonomického rozvoje kraje, úroveň sociálního kapitálu a výkon krajských vlád. Ostatní možné faktory potenciálně ovlivňující některou ze tří hlavních sledovaných proměnných budeme používat jenom jako kontrolní proměnné.

Výsledky analýz provedených v jiných zemích ukazují, že i pokud jsou nalezeny statisticky významné vztahy mezi ekonomickou výkonností regionů, jejich sociálním kapitálem a výkonem regionálních vlád, je obtížné ve vztazích mezi proměnnými odlišit př́íčiny a následky. Jedinou relativně spolehlivou metodou, jak se o identifikaci směru kauzality pokusit, je analýza delších časových řad, pomocí nichž lze konstruovat agregátní proměnné popisující ekonomickou výkonnost, sociální kapitál i výkon regionálních vlád v různých časových obdobích. Testování vzájemných vztahů mezi proměnnými charakterizujícími situaci v různých časových obdobích, pak dává možnost odlišit potenciální příčiny (časově předcházející) od potenciálních následků (časově následné). Vzhledem $\mathrm{k}$ tomu, že $\mathrm{v}$ českém kontextu nemáme $\mathrm{k}$ dispozici delší časové řady ukazatelů popisující zároveň ekonomickou výkonnost, sociální kapitál i výkon krajských vlád, nebudeme se pokoušet o hledání kauzálních vztahů mezi proměnnými, tedy o odlišení nezávisle a závisle proměnných, ale spíše o prosté hledání statistických souvislostí mezi proměnnými bez určení směru kauzality. Využijeme koncept „sociálního ekvilibria“ a budeme se primárně zajímat o to, jestli existující rozdíly mezi kraji v České republice naznačují ustavování vzájemně odlišných

${ }^{15}$ Agregované proměnné mívají často nižší variabilitu než dílčí proměnné, protože se extrémní hodnoty jednotlivých dílčích proměnných vzájemně částečně "kompenzují" a v agregátních indexech se jejich vliv stírá. Menší variabilita proměnných a méně extrémních hodnot má často za důsledek zmenšování hodnot korelačních koeficientů mezi proměnnými. 
„sociálních ekvilibrií“ v různých krajích, respektive v různých částech republiky. Naše dvě klíčové otázky zní: Existují statistické souvislosti mezi ekonomických vývojem, úrovní sociálního kapitálu a výkonem vlád na úrovni krajů v České republice? Jsou některé kraje konzistentně podprůměrné či konzistentně nadprůměrné v hodnotách všech sledovaných ukazatelů?

Jak již bylo výše naznačeno, jednotkou sledování nám budou kraje České republiky. Volba této územní jednotky byla jednoznačně určena tím, že se jedná o jediný územní celek na regionální úrovni, který má svoje vlastní přímo volené orgány, tedy krajskou vládu, jejíž výkon lze měřit. Nevýhodou krajů je samozřejmě to, že jako samostatné územní celky s vlastními vládami existují až od roku 2000, tedy velmi krátce. Naše analýzy tak zachycují situaci v období zrodu a postupného etablování krajů jako institucí, což může být období z dlouhodobého pohledu na jejich fungování ne úplně typické. Je nutné mít také na paměti, že z hlediska dvou dalších sledovaných proměnných - ekonomické výkonnosti a úrovně sociálního kapitálu - nejsou kraje jako územní jednotky sledování nijak ideální. Kraje České republiky jsou totiž vnitřně dosti heterogenní jednotky, takže se při práci s ukazateli popisujícími kraje jako celky ztratí nezanedbatelná část územní variability mezi sledovanými proměnnými. Konečně je nutné upozornit na to, že jsme se ze sledovaného souboru krajů rozhodli vyřadit Prahu, která je velmi netypickým krajem, těžko srovnatelným s ostatními kraji. Část odlišností je způsobena institucionálními rozdíly - Praha je samostatným městem se statutem kraje. Proto nejsou některé ukazatele vůbec k dispozici (v Praze se např. nekonají krajské volby, funkci krajského zastupitelstva vykonává městské zastupitelstvo), jiné formálně existují, ale nejsou srovnatelné s ukazateli charakterizujícími ostatní kraje (např. struktura rozpočtových př́ijmů a výdajů je zcela odlišná od „normálních“ krajů, míra důvěry v krajská zastupitelstva u pražských respondentů vypovídá o něčem jiném než obdobný ukazatel v jiných krajích). U ukazatelů, podle kterých lze věcně srovnávat Prahu s ostatními kraji, je navíc hodnota ukazatele pro Prahu často "mimo škálu“ (např. HDP na obyvatele, míra nezaměstnanosti, řada ukazatelů výkonu krajských vlád...), takže se při následných analýzách naráží na problém Prahy coby "outliera“, kterého většina statistických procedur doporučuje vyřadit.

\section{Operacionalizace proměnných}

Abychom popsali stupeň ekonomického rozvoje krajů, úroveň jejich sociálního kapitálu a výkon jejich krajských vlád, shromáždili jsme data z nejrůznějších zdrojů. U ukazatelů ekonomického rozvoje krajů, které jsou relativně nejsnáze dostupné, jsme zachytili stav ve dvou různých časových obdobích - kolem roku $1995^{16}$ a kolem roku 2005. Ukazatele vztahující se k úrovni sociálního kapitálu

\footnotetext{
${ }^{16}$ Dnešní kraje v roce 1995 ještě neexistovaly. Ukazatele ekonomické úrovně vztahující se $\mathrm{k}$ tomuto období vznikly přepočtením hodnot jednotlivých ukazatelů na území dnešních krajů.
} 
v krajích je mnohem komplikovanější zjistit retrospektivně, většina $\mathrm{z}$ nich proto popisuje současnou situaci, tedy období 2004-2006. Získat spolehlivé údaje o výkonu vlád je obecně dosti složité [Kostelecký, Patočková 2006]. V konkrétním případě krajských vlád v České republice je to ještě o to komplikovanější, že krajské vlády vznikly až v roce 2000 a teprve postupně přebíraly stále více zodpovědnosti za svěřené oblasti správy, jejich práci proto nebylo ani možné, ani smysluplné hodnotit za delší časové období. Všechny dílčí ukazatele charakterizující výkon krajských vlád tak pocházejí také z období 2000-2006. Ve všech třech případech jsme vytvořili agregátní indexy, které nejobecnějším způsobem charakterizují úroveň kraje v dané sledované oblasti. Postup při konstrukci agregátních indexů byl ve všech případech stejný: nejprve jsme škály u všech indikátorů změnili tak, aby zvyšování hodnoty ukazatele mělo ve všech případech stejný věcný smysl, tj. znamenalo vyšší ekonomický výkon, vyšší úroveň sociálního kapitálu, resp. lepší výkon vlády. Ve druhém kroku jsme jednotlivé indikátory převedli do podoby z-score, ${ }^{17}$ čímž jsme zajistili, že všechny proměnné měly v agregátním indexu stejnou váhu. Nakonec jsme hodnoty jednotlivých ukazatelů agregovali.

Agregátní index ekonomické výkonnostiti ${ }^{18}$ kraje byl vytvořen tak, aby postihnul více rysů ekonomické situace než jenom běžně používaný ukazatel HDP. Uvažovali jsme proto jak HDP v přepočtu na 1 obyvatele, tak HDP v přepočtu na 1 zaměstnance (koriguje údaje o ekonomické produkci kraje o saldo dojížd'ky a vyjížd'ky za prací), čistý disponibilní důchod domácnosti v přepočtu na obyvatele (je indikátorem kupní síly obyvatel), počet fyzických osob registrovaných k platbě DPH (je mírou ekonomické aktivity soukromých podnikatelů, nebere přitom v potaz drobné podnikatele s malými obraty, podnikající jen „na vedlejší úvazek" a vlastníky nevyužívaných živnostenských listů) a míru nezaměstnanosti. Výsledný agregátní index ekonomické výkonnosti byl nakonec vypočítán jako prostý průměr z jednotlivých dílčích ukazatelů.

Agregátní index úrouně sociálního kapitálu vycházel z Putnamova [Putnam 1993] konceptu měření míry občanskosti v italských regionech, který byl posléze doplněn a dopracován jako koncept měření úrovně sociálního kapitálu [např. Leonardi 1993; Putnam 2000]. V českých poměrech musel být index přizpůsoben dostupnosti konkrétních indikátorů, takže jeho konkrétní verze zahrnovala následující dílčí ukazatele: počet nestátních neziskových organizací v přepočtu na 1000 obyvatel (coby ukazatel „hustoty“ neziskových organizací v kraji), podíl lidí, kteří čtou regionální noviny, celostátní deníky a sledují zpravodajství v televizi (jako indikátory zájmu o veřejné věci), důvěra prezidentovi, důvěra krajským zastupitelstvům a důvěra obecním zastupitelstvưm (jako indikátory institucio-

\footnotetext{
17 Proměnné jsou bez ohledu na původní škály a variabilitu transformovány tak, aby průměrná hodnota byla 0 , nadprůměrné hodnoty byly kladné a podprůměrné byly záporné, přičemž hodnoty z-score udávají počet standardních odchylek, o který se měření odlišuje od průměrné hodnoty.

${ }^{18}$ Jednotlivé ukazatele sloužící k vytvoření agregátního indexu ekonomické výkonnosti a agregátního indexu úrovně sociálního kapitálu jsou uvedeny s př́íslušným zdrojem dat a roky, k nimž se konkrétní ukazatele vztahují, v př́loze 1.
} 
nální důvěry), počet dobrovolných dárců krve v přepočtu na 1000 obyvatel ${ }^{19}$ (jako indikátor generalizované důvěry), průměrná volební účast ve volbách do Poslanecké sněmovny, průměrná volební účast ve volbách do krajských zastupitelstev a účast $\mathrm{v}$ referendu o vstupu do Evropské unie (jako ukazatele politické participace obyvatel kraje). Stejně jako v předchozím případě jsme agregátní index sociálního kapitálu vypočetli prostým zprůměrňováním hodnot jednotlivých dílčích ukazatelů.

Agregátní index výkonu krajské vlády a způsob jeho vytvoření byl podrobně popsán v jiném článku tohoto monočísla [Illner et al. 2007]. Na tomto místě se proto jen omezíme na konstatování, že do indexu se promítnuly dílčí ukazatele charakterizující výkon krajských vlád v následujících oblastech: investice kraje a podpora podnikatelského a občanského sektoru, nákladnost výkonu krajské vlády, kvalita managementu veřejné správy vykonávané krajem, legislativní iniciativa kraje, kvalita správní činnosti v rámci přenesené působnosti kraje, vytváření podmínek pro rozvoj středního školství, uplatnění absolventů středních škol, vytváření podmínek pro rozvoj sociální péče, zahraniční aktivity kraje, kvalita internetových stránek kraje a poskytování informací. Abychom pracovali u všech tří sledovaných kategorií s porovnatelnými škálami agregátních indexů, upravili jsme hodnoty agregátního indexu výkonu krajských vlád uvedené v Illner et al. [2007], převedením na z-score.

\section{Výsledky analýzy}

$\mathrm{V}$ této části textu se pokusíme na základě analýzy dat odpovědět na výše uvedené klíčové otázky, které jsme si položili. Protože jsme neměli ambici zjištovat, která $\mathrm{z}$ proměnných je $\mathrm{v}$ daném vztahu př́ćčinou a která následkem, použili jsme v prvním kroku pro hledání statistických souvislostí jednoduché grafy doplněné o Pearsonovy korelační koeficienty. Zaměřili jsme se na situaci kolem roku 2005, protože jsme měli pro toto období relativně nejvíce spolehlivých ukazatelů.

\footnotetext{
${ }^{19}$ Jsme si vědomi, že existuje mnoho „standardnějších“ ukazatelů, které bývají používány jako indikátory generalizované důvěry (např. souhlas s výrokem: „Většině lidí je možné věřit.“). Žádný ze standardních indikátorù ovšem není možné kvưli neexistenci spolehlivých dat použít $\mathrm{k}$ měření rozdílů mezi kraji České republiky. Protože některé v zahraničí provedené studie úspěšně použily dárcovství krve jako míru generalizované důvěry [např. Guiso, Sapienza, Zingales 2004] nebo alespoň upozornili na pozitivní korelace mezi dárcovstvím krve a generalizovanou důvěrou [Putnam 2000; Uslaner 2000], rozhodli jsme se proto tohoto netradičního ukazatele, vzhledem $\mathrm{k}$ jeho dostupnosti podle jednotlivých krajů, použít také.
} 
Souvislosti mezi ekonomickým vývojem, sociálním kapitálem a výkonem krajských vlád kolem roku 2005

Graf 1. Závislost mezi výkonem krajské vlády a úrovní ekonomické výkonnosti kraje $\mathrm{v}$ roce 2005

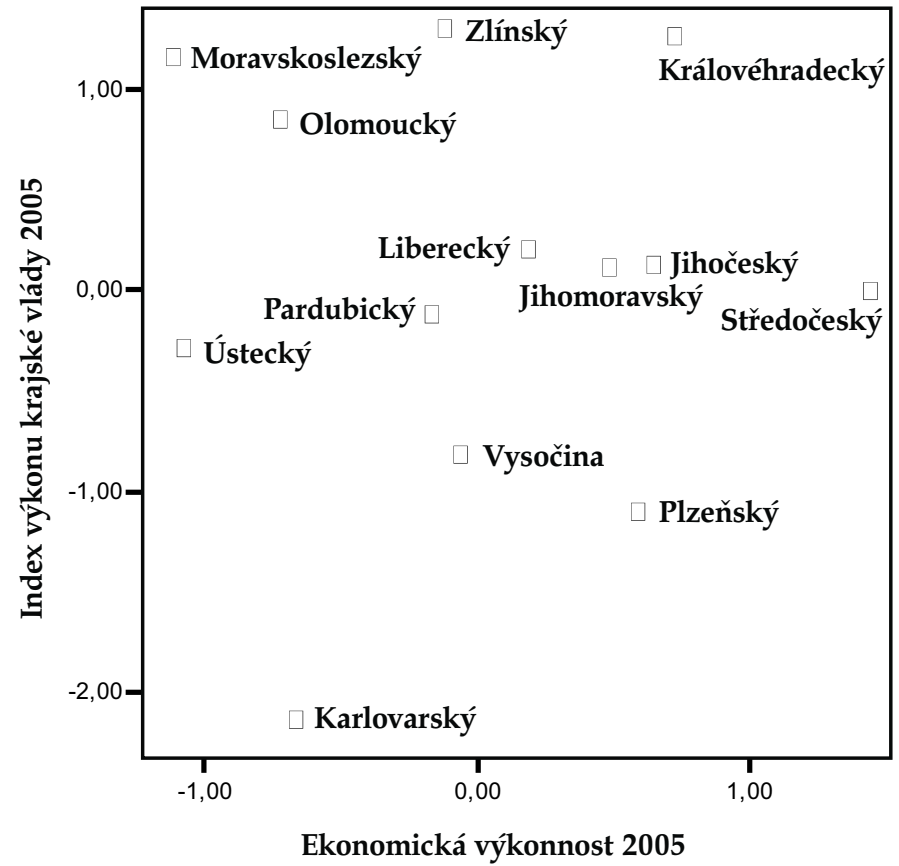

Zdroj: vlastní výpočty.

Graf 1 ukazuje na vztah mezi ekonomickou výkonností kraje a výkonem krajské vlády v období kolem roku 2005. Údaje v grafu nenaznačují žádný statistický vztah mezi sledovanými proměnnými. To je potvrzeno i prakticky nulovou hodnotou korelačního koeficientu $(\mathrm{R}=0,02, \mathrm{p}=0,957)$. Je zřejmé, že na úrovni krajů v České republice nebylo v období kolem roku 2005 možné identifikovat žádnou souvislost mezi ekonomickou výkonností kraje a výkonem krajských vlád. Nejvýkonnější krajské vlády bylo možno nalézt jak v krajích se špatnou ekonomickou situací (např. Moravskoslezský kraj), tak i v krajích s ekonomickou situací dobrou (např. Královéhradecký kraj). Podobně tak i platilo, že vysoká ekonomická výkonnost kraje automaticky nezaručovala vyšší výkon jeho vlády, než byl v krajích s ekonomickými potížemi (prakticky shodný výkon krajské vlády byl zaznamenán u tak ekonomicky odlišných krajů, jako je Ústecký a Středočeský). 
Graf 2. Závislost mezi úrovní sociálního kapitálu v kraji a výkonem krajské vlády $\mathrm{v}$ roce 2005

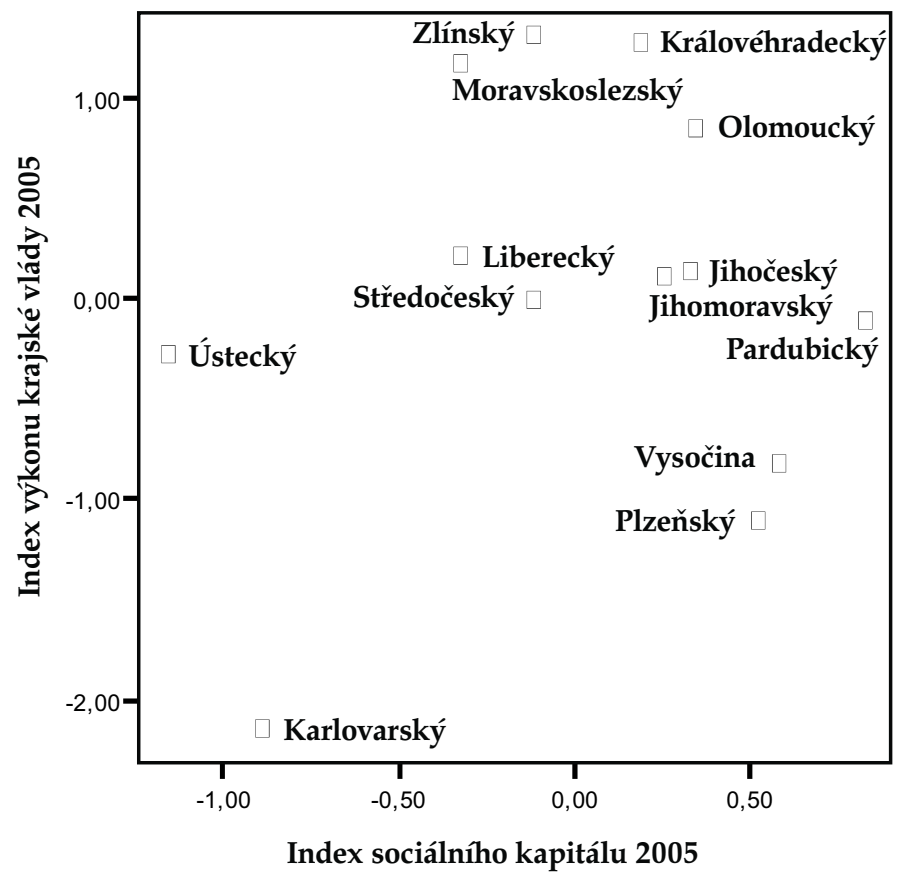

Zdroj: vlastní vópočty.

Vztah mezi výkonem krajských vlád a úrovní sociálního kapitálu je zachycen $\mathrm{v}$ grafu 2. Z pohledu na graf je patrné, že mezi oběma sledovanými proměnnými existuje pouhý náznak pozitivní korelace, která je ovšem velmi slabá a statisticky nevýznamná $(\mathrm{R}=0,16, \mathrm{p}=0,611)$. Nelze sice nalézt kraje, které by měly zároveň velmi vysokou úroveň sociálního kapitálu a velmi špatný výkon vlády, stejně jako kraje s velmi vysokým výkonem vlády a zároveň velmi nízkou úrovní sociálního kapitálu, v zásadě ovšem platí, že obě proměnné jsou nezávislé. Vysoký sociální kapitál není podmínkou výborného fungování krajské vlády, stejně jako dobrý výkon krajské vlády se automaticky nepromítá do vysoké úrovně sociálního kapitálu ve vládou spravovaném území.

Graf 3 ukazuje na souvislost mezi úrovní sociálního kapitálu a ekonomickou výkonností kraje. Z grafu je patrné, že určitá pozitivní korelace se dá v tomto př́ipadě zaznamenat, není však př́liš silná $(R=0,44)$ a nesplňuje konvenční pravidla kladená na statistickou významnost při takto malém počtu jednotek $(\mathrm{p}=0,132)$. 
Graf 3. Závislost mezi úrovní sociálního kapitálu v kraji a úrovní ekonomické výkonnosti kraje v roce 2005

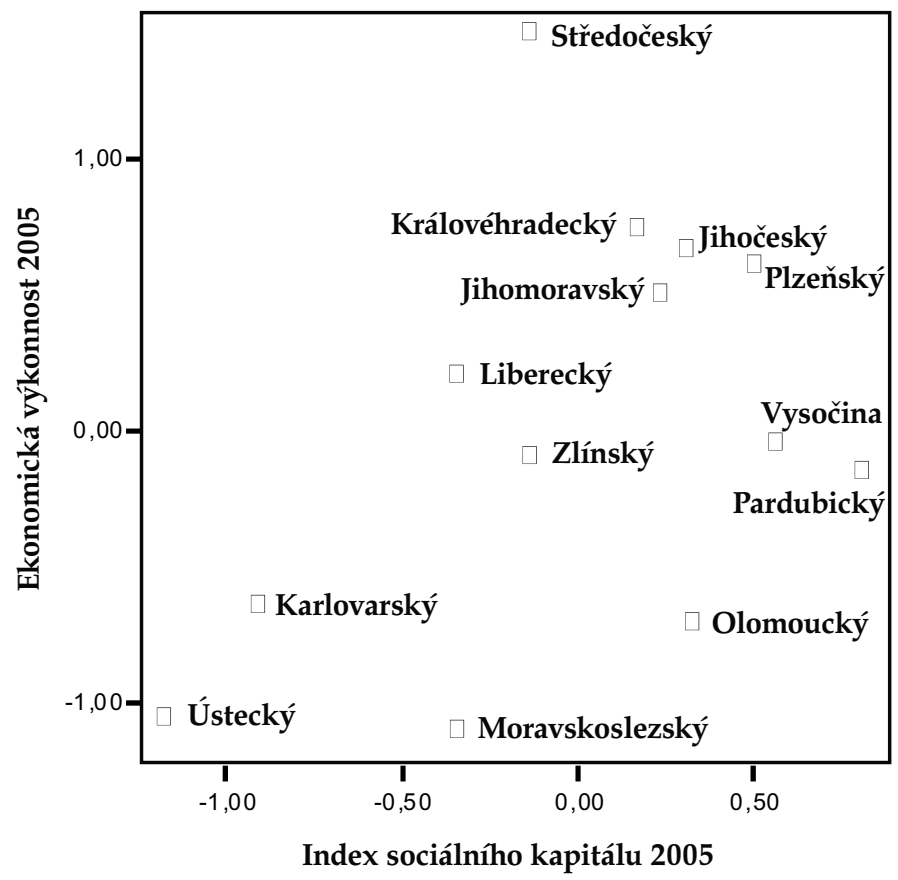

Zdroj: vlastní výpočty.

Z grafu je patrné, že body charakterizující polohu krajů v grafu se prakticky nevyskytují nad diagonálou spojující levý spodní a pravý horní vrchol čtverce tvořícího rámec grafu. To v praxi znamená, že ekonomická výkonnost bud' odpovídá úrovni sociálního kapitálu v kraji (Ústecký, Karlovarský, Zlínský, Liberecký, Královéhradecký, Jihomoravský, Jihočeský a Plzeňský) nebo je nižší (Moravskoslezský, Olomoucký, Pardubický a Vysočina). Jedinou výjimku z tohoto pravidla představuje Středočeský kraj, jehož relativně velmi vysoká ekonomická výkonnost neodpovídá pouze průměrným hodnotám indexu sociálního kapitálu. Pro tuto výjimku je však možné snadno najít vysvětlení v př́iznivém ekonomickém působení Prahy na celý středočeský region. V každém případě je zřejmé, že neexistují kraje, které by měly zároveň vysokou ekonomickou výkonnost a nízkou úroveň sociálního kapitálu.

Výsledky korelačních analýz nepotvrzují Putnamovu hypotézu o významných souvislostech mezi sociálním kapitálem regionu, jeho ekonomickým rozvojem a výkonem regionálních vlád v českém kontextu. Existuje sice jistá souvislost mezi úrovní sociálního kapitálu a ekonomickou výkonností kraje, není však nijak 
silná a nadto nevypadá jako souvislost lineární, ale je komplikovanější. Je ovšem možné, že vztahy mezi sociálním kapitálem, ekonomickou výkonností a výkonem krajských vlád přesto existují, ale v praxi je možné je zachytit až tehdy, sledujeme-li souvislosti mezi těmito charakteristikami krajů ve vývoji.

Souvislosti mezi ekonomickým vývojem, sociálním kapitálem a výkonem krajských vlád - pokus o dynamický pohled

Nemáme bohužel žádné údaje, které by dostatečně věrohodně zachycovaly vývoj úrovně sociálního kapitálu v krajích, ${ }^{20}$ a ani nemưžeme mít žádné údaje o eventuálním vývoji, pokud jde o výkon krajských vlád, protože ty vznikly až v roce 2000 a ještě nějakou dobu jim trvalo, než se fakticky ujaly svých nynějších kompetencí. Jediné ukazatele, které máme $\mathrm{k}$ dispozici v delších časových řadách, jsou ukazatele ekonomické výkonnosti krajů, u kterých se podařilo shromáždit dvě sady porovnatelných individuálních ukazatelů jednotlivých aspektů ekonomické výkonnosti za dvě různá období - relativně nejčerstvější data z období kolem roku 2005 a data z poloviny 90 . let 20. století. To nám umožnilo vytvořit ukazatel, který charakterizuje změnu v ekonomické výkonnosti kraje mezi sledovanými obdobími.

Graf 4 zachycuje souvislost mezi hodnotami ukazatele charakterizujícího změny v ekonomické výkonnosti mezi roky 1995 a 2005 a indexem sociálního kapitálu v období kolem roku 2005. Na první pohled je zřejmé, že mezi oběma proměnnými zachycenými v grafu existuje pozitivní korelace $(R=0,64)$, která je statisticky významná $(\mathrm{p}=0,018)$. V zásadě platí, že čím větší byla úroveň sociálního kapitálu v kraji kolem roku 2005, tím větší relativní zlepšení ekonomické výkonnosti mezi roky 1995 a 2005 bylo zaznamenáno. Jediným krajem, který se od zmíněného pravidla významněji odlišoval, byl Středočeský kraj, u něhož bylo možno, s největší pravděpodobností vlivem působení Prahy, pozorovat relativně největší zvýšení ekonomické výkonnosti při průměrných hodnotách úrovně sociálního kapitálu. ${ }^{21}$ Ze samotné korelace není samozřejmě jasné, co je př́ičinou a co je následkem. Pokud by byla pravda, že je úroveň sociálního kapitálu krajů relativně stabilní veličinou (a údaje o mezikrajských rozdílech ve volební účasti v období 1990-2006 tomu nasvědčují), dalo by se říci, že ekonomická situace v krajích se v období 1995-2005 relativně zlepšuje tím více, čím vyšší je v nich úroveň sociálnúho kapitálu. Nedá se ovšem ani vyloučit, že úroveň sociálního kapitálu v krajích se může měnit. Pak by ovšem byla teoreticky možná i opačná

\footnotetext{
${ }^{20}$ Máme sice k dispozici údaje o volební účasti od roku 1990 do roku 2006, na úrovni krajů jsou však hodnoty všech těchto ukazatelů vysoce pozitivně korelovány. Žádné jiné ukazatele charakterizující jednotlivé dimenze sociálního kapitálu před rokem 2004 nemáme $\mathrm{k}$ dispozici.

${ }^{21}$ Po vyřazení Středočeského kraje jako zvláštního případu dosahuje korelační koeficient dokonce hodnoty $R=0,78(p=0,003)$.
} 
Graf 4. Závislost mezi úrovní sociálního kapitálu a změnou ekonomické výkonnosti kraje v období mezi roky 1995 a 2005

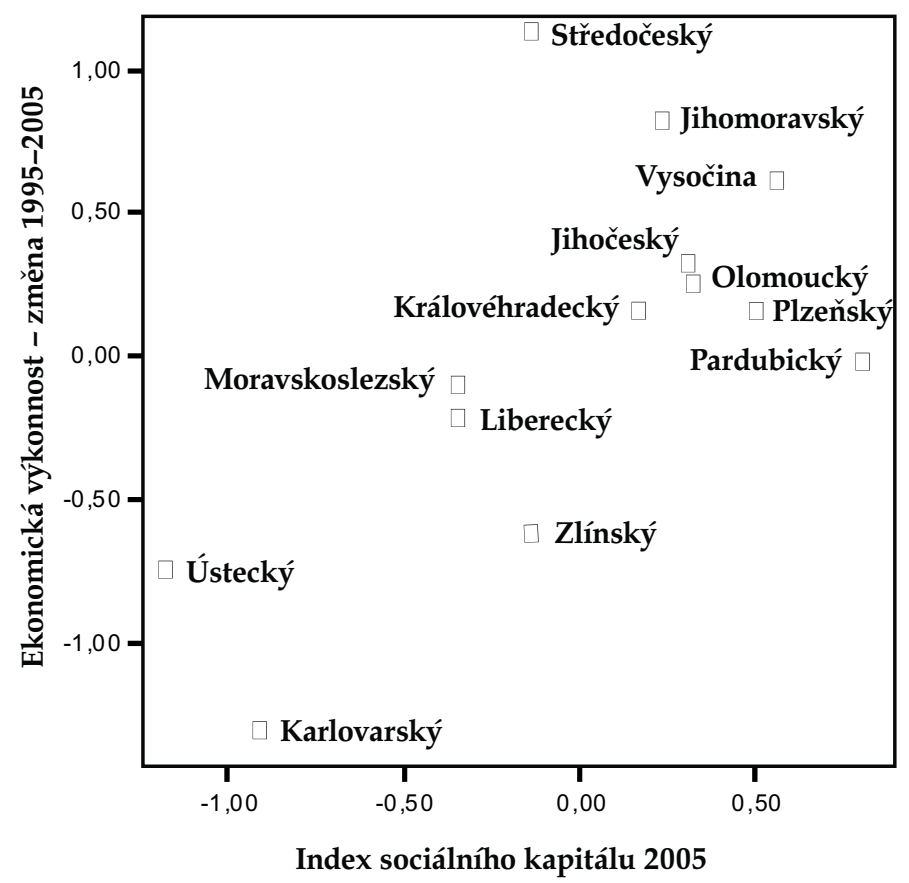

Zdroj: vlastní výpočty.

interpretace - zvyšování ekonomické výkonnosti v letech 1995-2005 napomáhalo budování sociálního kapitálu, takže v krajích, kde docházelo ve sledovaném období k největšímu zvyšování ekonomické výkonnosti, byla na konci sledovaného období zaznamenána nejvyšší úroveň sociálního kapitálu.

\section{Potenciální vliv dalšich faktorů}

Nakonec jsme si položili otázku, jestli existují nějaké další faktory, které by svým působením ovlivnily některé $\mathrm{z}$ námi sledovaných tří charakteristik krajů, případně všechny tři. Z literatury známe několik takových potenciálně vlivných proměnných, o jejichž působení na regionální úrovni jsme dosud vůbec neuvažovali: př́ijmové nerovnosti, etnická heterogenita, odlišný institucionální design samotných zkoumaných institucí, ideologické odlišnosti mezi politickými reprezentanty různých politických stran v exekutivních orgánech kraje, rozdíly v postojích a strategiích regionálních elit, působení dalších dosud neuvažovaných institucio- 
nálních faktorů, náboženské rozdíly a konečně odlišná úroveň lidského kapitálu v krajích. Některé z výše uvedených faktorů jsou v podmínkách České republiky zjevně nerelevantní. Příjmové nerovnosti sice v jednotlivých krajích existují, ale po vynechání Prahy ze souboru není míra příjmových nerovností (měřená např. rozdíly v př́ijmech lidí patřících do krajních kvartilů na příjmové škále, nebo rozdíly mezi průměrnými mzdami v jednotlivých okresech v rámci kraje) v krajích př́liš odlišná. Etnicky je Česká republika navzdory rostoucímu přistěhovalectví stále velmi homogenní, takže i v tomto ohledu jsou rozdíly mezi kraji zanedbatelné. Základní institucionální design krajských vlád byl nadiktován zákony, a ačkoliv existuje jistý prostor pro kraje, pokud jde o vytváření jejich vlastních institucí, uplynulo ještě př́iliš málo času na to, aby mohly být rozdíly významné.

Vztah ostatních potenciálně významných proměnných ${ }^{22} \mathrm{k}$ našim třem sledovaným charakteristikám krajů jsme empiricky testovali. V naprosté většině případů neexistují mezi proměnnými žádné korelace. Krajská zastupitelstva se sice poněkud liší v politickém složení, rady kraje už méně, nicméně ani jeden z ukazatelů popisujících složení zastupitelstev či rad krajů a jejich změny (Raeho index politické fragmentace, ${ }^{23}$ procento krajských zastupitelů či radních, kteří drželi své pozice po dvě volební období za sebou) nekoreloval se žádnou ze tří sledovaných charakteristik kraje. Podobně ekonomický rozvoj, úroveň sociálního kapitálu ani výkon krajské vlády nesouvisí s mírou optimismu krajských elit ohledně rozvojových možností kraje, jak byla zjištěna ve výběrovém šetření Regionální elity 2004 [Kostelecký, Vobecká 2005]. Je to pravděpodobně proto, že se samotné regionální elity nijak zvlášt ve svých postojích kraj od kraje neodlišují. Podobně nebyla nalezena žádná statisticky významná korelace ani s podílem věřících v populaci krajů.

\section{Lidský kapitál v krajích a jeho vliv na ostatní proměnné}

Jediné ukazatele, které významně korelovaly hned s několika námi sledovanými charakteristikami krajů, byly ukazatele popisující úroveň lidského kapitálu krajů, tedy vzdělanosti jejich obyvatel. Z několika námi použitých indikátorů vzdělanosti koreloval s ostatními ukazateli nejtěsněji podíl obyvatel s úplným středo-

\footnotetext{
22 Šlo o ukazatele charakterizující politické složení krajského zastupitelstva, míru kontinuity v zastupitelstvech (podíl krajských zastupitelů, kteří obhájili křeslo ve volbách 2004), míru politické fragmentace (Raeho index politické fragmentace), postoje krajských elit (podíl optimistů, pokud jde o rozvojové možnosti kraje), podíl věrících v populaci a vzdělanost (podíl obyvatel s minimálně středoškolským vzděláním ve věku 15 a více let, a ve věku 25-34 let, podíl vysokoškoláků v populaci starší 25 let a ve věku 25-34 let).

${ }^{23}$ Raeho index politické fragmentace měři pravděpodobnost, že dva náhodně vybraní členové zastupitelstva (rady) patří $\mathrm{k}$ různým stranám. Dosahuje hodnot $\mathrm{v}$ rozmezí od 0 (pokud všichni poslanci patří ke stejné straně) do 1 (pokud každý poslanec je členem jiné strany) - viz Rae [1971].
} 
Tabulka 1. Korelace mezi ukazateli ekonomické výkonnosti krajů, úrovní sociálního kapitálu v kraji, výkonu krajské vlády a míry vzdělanosti mladší generace

\begin{tabular}{|c|c|c|c|c|c|}
\hline & $\begin{array}{c}\text { Ekonomická } \\
\text { výkonnost } \\
1995\end{array}$ & $\begin{array}{c}\text { Ekonomická } \\
\text { výkonnost } \\
2005\end{array}$ & $\begin{array}{l}\text { Index } \\
\text { sociálního } \\
\text { kapitálu }\end{array}$ & $\begin{array}{l}\text { Index } \\
\text { výkonu } \\
\text { krajské } \\
\text { vlády }\end{array}$ & $\begin{array}{c}\text { Podíl lidí s minimál- } \\
\text { ně středoškolským } \\
\text { vzděláním ve věku } \\
25-34 \text { let }\end{array}$ \\
\hline $\begin{array}{l}\text { Ekonomická } \\
\text { výkonnost } 1995\end{array}$ & 1 & & & & \\
\hline $\begin{array}{l}\text { Ekonomická } \\
\text { výkonnost } 2005\end{array}$ &, $84^{* *}$ & 1 & & & \\
\hline $\begin{array}{l}\text { Index sociálního } \\
\text { kapitálu }\end{array}$ & 17 & ,44 & 1 & & \\
\hline $\begin{array}{l}\text { Index výkonu } \\
\text { krajské vlády }\end{array}$ &,- 23 & ,02 & ,16 & 1 & \\
\hline $\begin{array}{l}\text { Podíl lidí s mini- } \\
\text { málně středoškol- } \\
\text { ským vzděláním } \\
\text { ve věku 25-34 let }\end{array}$ & 23 & ,51 &, $76^{* *}$ &, $59 *$ & 1 \\
\hline
\end{tabular}

Zdroj: vlastní výpočty.

Poznámka: ** Korelace signifikantní na hladině $\mathrm{p}<0,01$,

* korelace signifikantní na hladině $\mathrm{p}<0,05$.

školským a vyšším vzděláním ve věkové kategorii 25-34 let ${ }^{24}$ v roce 2001 (viz tabulku 1).

Vzdělanost je pozitivně korelovaná se všemi zbylými ukazateli. Nejtěsnější je korelace s indexem sociálního kapitálu $(R=0,76, p=0,003)$, o něco méně silná, i když stále ještě statisticky významná, je pozitivní korelace s indexem výkonu vlády $(\mathrm{R}=0,59, \mathrm{p}=0,034)$. Platí tedy, že čím vzdělanější je populace kraje, tím větší hodnota sociálního kapitálu a tím lepší výkon krajské vlády se dá očekávat. Nebo naopak: v krajích s vyšší úrovní sociálního kapitálu se dá předpokládat vyšší vzdělanost populace a podobně v krajích s výkonnější vládou se dá očekávat vyšší vzdělanost populace. Existuje i pozitivní korelace mezi vzdělaností v kraji a jeho ekonomickou výkonností, ale tato korelace je slabší, takže není při malém počtu jednotek statisticky významná. Hodnota korelačního indexu mezi vzdělaností mladých v roce 2001 a ekonomickou výkonností kraje v roce 2005 je však už na hranici statistické významnost $(R=0,51, p=0,073)$.

${ }^{24}$ Rozdíly v míře korelace jsou mezi jednotlivými ukazateli vzdělanosti a ostatními charakteristikami kraje malé. Rozhodli jsme se použít podíl obyvatel s minimálně středoškolským vzděláním ve věku 25-34 let, protože není závislý na rozdílech ve věkové struktuře populace krajů a je méně ovlivněn stěhováním mezi kraji, než jsou ukazatele pracující pouze s počty vysokoškoláků. 
V každém případě je jisté, že vzdělanost obyvatel (nebo obecněji úroveň lidského kapitálu v kraji) je významným faktorem, který souvisí se všemi třemi námi sledovanými charakteristikami krajů. Vliv vzdělanosti na ostatní proměnné se ukázal být tak významný, že jsme si položili otázku, nakolik se změní korelace mezi třemi sledovanými proměnnými (zachycené $\mathrm{v}$ grafech 1-4), pokud budeme statisticky kontrolovat vliv rozdílné míry vzdělanosti. Vypočítali jsme proto parciální korelace a porovnali je s hodnotami prostých korelačních koeficientů. Výsledky srovnání jsou v tabulce 2.

Z výsledků v tabulce je zřejmé, že pokud je brán v úvahu vliv mezikrajských rozdílů $\mathrm{v}$ úrovni vzdělanosti, korelace mezi výkonem krajských vlád, úrovní sociálního kapitálu, ekonomickou výkonností kraje a změnou ekonomické výkonnosti kraje mezi roky 1995 a 2005 se podstatně změní. Korelace mezi úrovní sociálního kapitálu v krajích a jejich ekonomickým vývojem v letech 1995 až 2005 sice zůstala kladná, po kontrole vlivu vzdělanostních rozdílů se však její hodnota snížila hluboko pod hranici statistické významnosti. Kladná (leč statisticky nevýznamná) korelace mezi úrovní sociálního kapitálu a ekonomickou výkonností kraje v roce 2005 se po kontrole vlivu vzdělanosti mění na nulovou korelaci. Zdá se tedy, že rozdílný ekonomický rozvoj krajů spíše souvisí s rozdíly ve vzdělanostní úrovni než se samotným na vzdělání nezávislým působením sociálního kapitálu. Jestliže kontrolujeme vliv vzdělanosti, významně se mění i zbylé dvě korelace - z hodnot okolo nuly se posunují do záporných hodnot

Tabulka 2. Korelace mezi ukazateli ekonomické výkonnosti krajů, úrovní sociálního kapitálu v kraji a výkonu krajské vlády - porovnání prosté korelace a parciální korelace, při níž je jako kontrolní proměnná použita úroveň vzdělanosti populace kraje

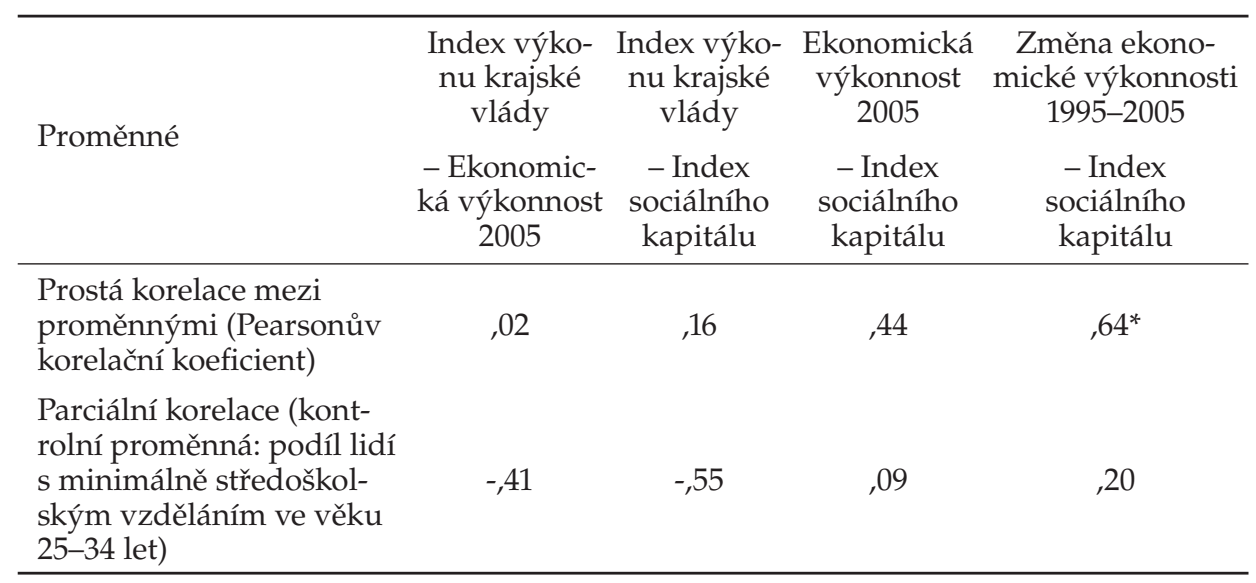

Zdroj: vlastní výpočty.

Poznámka: * Korelace signifikantní na hladině $\mathrm{p}<0,05$. 
(ačkoliv zůstávají pod hranicí statistické významnosti). Při vědomí statistické nevýznamnosti záporných parciálních korelací bychom tuto skutečnost mohli s opatrností interpretovat následovně: jestliže kontrolujeme vliv vzdělanostních rozdílů mezi kraji, výkon krajských vlád je negativně korelován s ekonomickou výkonností krajư i úrovní sociálního kapitálu v krajích. To by bylo poněkud překvapivé zjištění, protože negativní korelace se zdá naznačovat, že při kontrole vzdělanosti se výkon krajských vlád snižuje se vzrůstající ekonomickou výkonností kraje a vyšším sociálním kapitálem v kraji. Domníváme se proto, že pravděpodobnější by mohlo být "opačné“ vysvětlení - je možné, že politická reprezentace v krajích s relativně nižší ekonomickou výkonností a relativně nižší úrovní sociálního kapitálu je si těchto handicapů vědoma, a snaží se je proto kompenzovat svojí větší aktivitou a vyšší výkonností. Toto vysvětlení by ovšem šlo proti logice Putnamova uvažování o výkonnosti regionálních vlád jako odrazu úrovně sociálního kapitálu, eventuálně ekonomické výkonnosti regionu. Výkon vlády by nevyrůstal z prostředí, ve kterém vláda funguje, ale byl by důsledkem vědomé reakce na okolnosti, ve kterých vláda působí. Konečně se nedá vyloučit, že výše zmíněné statistické souvislosti jsou jenom statistickým artefaktem, způsobeným prací s malým počtem jednotek.

\section{Typologie kraju}

Nakonec nám zbývá odpovědět na otázku, jestli lze v českých poměrech nalézt kraje, které by byly typickými příklady ustavení některého z možných „,sociálních ekvilibrií" " Jinými slovy: existují kraje, ve kterých je možné identifikovat současně vysokou úroveň sociálního kapitálu, vysokou ekonomickou výkonnost a vysoký výkon krajských vlád, o nichž se lze domnívat, že se vzájemně podmiňují a pozitivními zpětnými vazbami navzájem posilují? A obdobně: lze identifikovat kraje, ve kterých lze současně zaznamenat nízkou úroveň sociálního kapitálu, nízkou ekonomickou výkonnost a špatný výkon krajské vlády, o nichž lze předpokládat, že jsou spolu navzájem propojeny systémem negativních zpětných vazeb?

Hodnoty všech tří agregátních ukazatelů ekonomické výkonnosti, sociálního kapitálu a výkonu krajských vlád (ve formě z-score), které se vztahují k časově srovnatelnému období kolem roku 2005, jsme použili jako vstupní proměnné do shlukové analýzy, ${ }^{25}$ která nám posloužila $\mathrm{k}$ vytvoření typologie krajů - viz tabulku 3.

Z tabulky je patrné, že o žádném z krajů v České republice kolem roku 2005 nelze hovořit jako o typickém př́íkladu územní jednotky, v níž došlo k ustavení „pozitivního sociálního ekvilibria“, v němž by byly zaznamenány významně nadprůměrné hodnoty ukazatelů ve všech třech námi sledovaných oblastech. U krajů prvního typu je sice možné zaznamenat nadprůměrnou ekonomickou výkonnost v kombinaci s nadprůměrným výkonem vlád, ovšem při jen průměr-

${ }_{25}$ Shluková analýza z balíku programů SPSS, metoda shlukování BAVERAGE. 
Tabulka 3. Typy krajů podle hodnoty ekonomické výkonnosti krajů, úrovně sociálního kapitálu a výkonu krajských vlád v období kolem roku 2005

\begin{tabular}{|c|c|c|c|c|}
\hline \multirow{2}{*}{$\begin{array}{l}\text { Číslo } \\
\text { typu }\end{array}$} & \multirow{2}{*}{ Kraje př́slušející k danému typu } & \multicolumn{3}{|c|}{$\begin{array}{c}\text { Průměrná standardizovaná } \\
\text { hodnota ukazatele }\end{array}$} \\
\hline & & $\begin{array}{l}\text { Ekonomická } \\
\text { výkonnost }\end{array}$ & $\begin{array}{l}\text { Sociální } \\
\text { kapitál }\end{array}$ & $\begin{array}{l}\text { Výkon kraj- } \\
\text { ských vlád }\end{array}$ \\
\hline \multirow{3}{*}{1} & Jihočeský, Jihomoravský & \multirow{3}{*}{,72 } & \multirow{3}{*}{, 04} & \multirow{3}{*}{, 45} \\
\hline & Středočeský, Liberecký & & & \\
\hline & Královéhradecký, Zlínský & & & \\
\hline 2 & Karlovarský, Ústecký & $-1,14$ & $-1,79$ & $-1,25$ \\
\hline 3 & $\begin{array}{l}\text { Plzeňský, Pardubický } \\
\text { Vysočina }\end{array}$ & ,14 & 1,10 &,- 72 \\
\hline 4 & Olomoucký, Moravskoslezský & $-1,22$ & 00 & 96 \\
\hline
\end{tabular}

Zdroj: vlastní výpočty.

né úrovni sociálního kapitálu. Naopak kraje, které bylo možné považovat za př́íklady „negativního sociálního ekvilibria“, jsou hned dva - Ústecký a Karlovarský. Oba tyto kraje se vyznačují kombinací významně negativního hodnocení ve všech třech sledovaných oblastech. Zbylé dva typy krajů vykazují „rozporuplné“ výsledky. Kraj Plzeňský, Pardubický a Vysočina mají vysokou úroveň sociálního kapitálu, jen průměrné ekonomické výsledky a podprůměrný výkon vlád. Moravskoslezský a Olomoucký kraj jsou ekonomicky vůbec nejslabší, mají průměrnou úroveň sociálního kapitálu, ale výkon jejich krajských vlád byl hodnocen jako velmi dobrý.

\section{Závěr}

Zkoumání souvislostí mezi ekonomickou výkonností krajů, sociálním kapitálem v krajích a výkonem krajských vlád zařadilo případ České republiky mezi země, v nichž nebyly potvrzeny Putnamovy hypotézy o vzájemných souvislostech těchto tř́ jevů na regionální úrovni. Jinak řečeno: $\mathrm{v}$ rámci použité metodiky a s využitím dat, které jsme měli $\mathrm{k}$ dispozici, nebylo možno prokázat souvislost mezi výkonem krajských vlád a stupněm ekonomického rozvoje krajů, stejně jako mezi výkonem krajských vlád a úrovní sociálního kapitálu v krajích. Existuje sice jistá pozitivní souvislost mezi úrovní sociálního kapitálu v kraji a jeho ekonomickou výkonností, zjištěná souvislost však není př́liš těsná. Pro tento výsledek existuje několik možných vysvětlení. Předně je možné, že Putnamem formulovaná hypotéza není tak univerzální, jak se mnohým zdá. Milner a Ersson [Milner, Ersson 2000] upozorňují na to, že vztah mezi sociálním kapitálem, ekonomickou výkon- 
ností a výkonem regionálních vlád může existovat, nemusí však být jednoduše lineární. Porovnáváme-li země nebo regiony, které se výrazně liší v hodnotách tří sledovaných proměnných (např. Albánie versus Dánsko, nebo jih versus sever Itálie), velmi pravděpodobně najdeme statisticky významné souvislosti mezi proměnnými. Budeme-li však porovnávat země nebo regiony, které se od sebe hodnotami sledovaných proměnných př́liš neliší (skandinávské země nebo regiony v Kanadě), pravděpodobnost nalezení statisticky významných souvislostí se podstatně zmenší. To by mohl být případ i českých regionů, které jsou relativně málo vzájemně odlišné.

Skutečnost, že výkon krajských vlád nekoreluje ani s ekonomickou úrovní kraje, ani s úrovní sociálního kapitálu v kraji, naznačuje, že výkon vlády nějakého kraje nemusí být tolik závislý na ostatních charakteristikách kraje, jak Putnamova hypotéza očekává. Do výkonu krajské vlády se mohou významně promítat postoje, aktivita nebo složení regionálních elit. Z našich předchozích výzkumů [Kostelecký, Vobecká 2005] víme, že se v České republice elity v různých krajích př́liš neliší, nelze je tedy jednoduše považovat za „produkty“ ekonomického a sociálního prostředí, $v$ němž působí. Významnou roli zřejmě mohou hrát i konkrétní osobnosti v čele krajských vlád - kupříkladu velmi dobrý výkon vlády Moravskoslezského kraje, který je jinak krajem značně problémovým, by mohl souviset s pưsobením všeobecně uznávaného a respektovaného hejtmana Tošenovského a jeho týmu.

Je také možné, že Putnam ve své hypotéze podcenil vliv dalších faktorů, které mohou ovlivňovat jak ekonomickou výkonnost, sociální kapitál, tak výkon regionálních vlád. Za zvláštní zmínku stojí minimálně faktory geografické (např. centrální versus periferní poloha v rámci České republiky, sousedství s bohatými zahraničními regiony versus sousedství s chudými zahraničními regiony, odlišnosti v míře urbanizace...), a také vliv regionálních rozdílů v úrovni lidského kapitálu. Vliv geografických faktorů nelze podceňovat, studium jejich potenciálního vlivu na ekonomickou výkonnost, sociální kapitál i výkon krajských vlád však přesahuje záběr tohoto článku, takže jsme se jimi úmyslně nezabývali. Rozdíly v úrovni lidského kapitálu, který jsme v našem př́ípadě měřili vzdělaností obyvatel, mohou hrát v rozvoji krajů významnou roli. Ukazuje se, že v krajích s vyšší vzdělaností je i vyšší sociální kapitál a lépe v nich fungují krajské vlády. Pozitivní vztah mezi úrovní vzdělanosti a ekonomickou výkonností kraje existuje také, i když je slabší. Vzdělanost obyvatel je nějakým způsobem spojena se všemi třemi námi sledovanými ukazateli fungování krajů. V krajích se vzdělanějším obyvatelstvem bývá zaznamenán rychlejší ekonomický rozvoj [Blažek, Uhlír 2002], vzdělanost obyvatel pozitivně souvisí s úrovní sociálního kapitálu [Stachová 2005], jak ukazují naše analýzy, vzdělanost obyvatel kraje pozitivně koreluje i s výkonem krajských vlád. Tyto vztahy jistě stojí za hlubší prozkoumání.

Konečně poslední z možných vysvětlení, proč jsme na úrovni českých krajů kolem roku 2005 nenalezli významné souvislosti mezi ekonomickým rozvojem, sociálním kapitálem a výkonem krajských vlád, je založeno na úvaze, že 
tyto vztahy potřebují delší dobu na to, aby se mohly zformovat. Je zřejmé, že náš pohled na situaci se změní, pokud se na vzájemné vztahy tř́ zkoumaných kategorií podíváme dynamicky a sledujeme nejen stav k určitému období, ale i vývoj veličin v čase. Výsledky našich analýz, vzhledem k nedostatku datových zdrojů charakterizujících úroveň sociálního kapitálu hlouběji do minulosti a krátké době existence krajských vlád omezené pouze na sledování souvislostí mezi vývojem ekonomické výkonnosti a ostatními dvěma kategoriemi ve stavu kolem roku 2005, naznačují silnější souvislosti mezi proměnnými. Kraje s vyšší úrovní sociálního kapitálu vykazovaly v letech 1995-2005 významně vyšší tempa ekonomického rozvoje než kraje s nízkou úrovní sociálního kapitálu. Podobně i výkon krajských vlád koreloval silněji s ukazatelem změny ekonomické výkonnosti než s ukazateli charakterizujícími ekonomickou výkonnost $\mathrm{v}$ určitém konkrétním roce. Zdá se tedy, že ještě není na místě Putnamovu hypotézu zcela odmítat. Bude rozumnější, když se za nějaký čas $k$ tématu vrátíme a znovu změříme ekonomickou výkonnost, úroveň sociálního kapitálu i výkon krajských vlád. To nám umožní použít dynamické ukazatele charakterizující změny v jednotlivých oblastech a s tím otevřít i otázku kauzality, kterou jsme se v tomto našem prvním pokusu o sledování vztahu mezi ekonomickým rozvojem, sociálním kapitálem a výkonem krajských vlád v České republice nemohli zabývat.

TOMÁš KosteleCKÝ je vědecký pracovník Sociologického ústavu AV ČR, vedoucí oddělení Lokální a regionální studia. Dlouhodobě se zabývá prostorovými aspekty lidského chování, lokální, regionální a komparationí politikou, politickými důsledky metropolizace a suburbanizace. Pravidelně publikuje $v$ domácích $i$ zahraničních odborných časopisech a knihách.

VĚRA PATOČKOVÁ je absolventka magisterského studia kulturologie na Filozofické fakultě UK v Praze, kde v současné době pokračuje v doktorském studiu. Absolvovala rovněž studijni program WLRA International Centre of Excellence v Nizozemí (M.A. in international leisure studies). $V$ současné době pracuje jako odborná pracovnice Sociologického ústavu $A V$ ČR v oddělení Lokální a regionální studia.

JANA VoBeCKá je studentkou doktorského studia demografie na Př́rodovědecké fakultě UK v Praze a na Université de Bourgogne v Dijonu. Ve své výzkumné práci se zaměřje na prostorové aspekty demografického chování a socioekonomických charakteristik obyvatel. Vedle toho se také věnovala studiu demografického chování Židio v Čechách v minulosti.V současné době pracuje jako odborná pracovnice Sociologického ústavu AV ČR v oddělení Lokální a regionální studia. 
Tomáš Kostelecký, Věra Patočková, Jana Vobecká: Kraje v České republice

\section{Literatura}

Almond, G. A., S. Verba. 1963. The Civic Culture: Political Attitudes and Democracy in Five Nations. Princeton: Princeton University Press.

Ardy, B., J. Gower. 2002. „Books on European Integration.“ Journal of Common Market Studies 40: 207-215.

Baldersheim, H., M. Illner, H. Wollmann (eds.). 2003. Local Democracy in Post-Communist Europe. Opladen: Leske + Budrich.

Balík, S., Koloušek, J. (eds.). 2005. Krajské volby v České republice 2004. Brno: Masarykova Univerzita v Brně, Mezinárodní politologický ústav.

Barrileaux, Ch., R. Feiock, R. E. Crew. 1992. „Measuring and Comparing the American States' Administrative Characteristics." State and Local Government Review 24 (1): 12-18.

Barro, R. J., X. Sala-i-Martin. 1991. „Convergence across States and Regions.“ Brookings Papers on Economic Activity 1: 107-182.

Beugelsdijk, S., T. von Schaik, W. A. Arts. 2006. „Toward a unified Europe? Explaining cultural differences by economic development, cultural heritage and historical shocks." Regional Studies 40 (3): 317-328.

Blažek, J. 1999. ",Regional development and regional policy in Central East European countries in the perspective of the EU eastern enlargement." Pp. 181-208 in Martin Hampl et al. Geography of Societal Transformation in the Czech Republic. Praha: Př́rodovědecká fakulta UK.

Blažek, J., P. Csank. 2007. „Nová fáze regionálního rozvoje v ČR?“ Sociologický časopis / Czech Sociological Review 43 (5): 945-965.

Blažek, J., Uhlíř, D. 2002. Teorie regionálního rozvoje. Praha: Karolinum.

Boix, C., D. Posner. 1998. „Social capital: Explaining Its Origins and Effects on Government Performance." British Journal of Political Science 28 (4): 686-695.

Bourdieu, P. 1986. „The Forms of Capital.“ Pp. 241-258 in J. Richardson (ed.). Handbook of Theory and Research in Sociology of Education. New York: Greenwood.

Brustein, W. 1988. The Social Origin of Political Regionalism: France, 1849-1981. Berkeley: University of California Press.

Buttrick, S., J. P. Moran. 2005. „Russia's Missing Link? Social Capital, Entrepreneurialism, and Economic Performance in Post-communist Russia." Communist and PostCommunist Studies 38 (3): 357-368.

Callois, J.-M. 2006. "Social Capital and Economic Performance: An Econometric Test on French Rural Areas." Revue d'Economie Régionale et Urbaine 6 (2): 227-243.

Campo, C. del, C. M. F. Monteiro, J. O. Soares. 2006 „The Socioeconomic Diversity of European Regions." Working Paper Series The Harvard Center for European Studies 131. Berlin: The Harvard Center for European Studies.

Casey, T. 2004. „Social Capital and Regional Economies in Britain.“ Political Studies 52 (1): 96-117.

Casey, T., K. Christ. 2005. „Social Capital and Economic Performance in the American States." Social Science Quarterly 86 (4): 826-845.

Coffé, H., B. Geys. 2005. „Institutional Performance and Social Capital: An Application to the Local Government Level." Journal of Urban Affairs 27 (5): 485-501.

Coleman, J. 1988. "Social Capital in the Creation of Human Capital.“ American Journal of Sociology 94: 95-120.

Cusack, T. R. 1999. „Social Capital, Institutional Structures and Democratic Performance. A Comparative Study of German Local Governments." European Journal of Political Research 35: 1-34.

Čermák, D., J. Stachová, J. Vobecká. 2007. Regionální rozdíly v úrovni sociálnîho kapitálu $v$ České republice. Nepublikovaný rukopis/Unpublished manuscript. 
Daněk, P. 2000. „Nerovnoměrný rozvoj světa: kolonialismus, neokolonialismus a diskurz rozvoje." Pp. 29-58 in P. Jehlička, J. Tomeš, P. Daněk. Stát, prostor, politika. Vybrané otázky politické geografie. Praha: Přírodovědecká fakulta Univerzity Karlovy.

Dahl, R. A. 1989. Democracy and its critics. New Haven: Yale University Press.

Edwards, B., M. W. Foley. 1998. "Social Capital and Civil Society Before Putnam." American Behavioral Scientist 42 (1): 124-139.

Gorzelak, G., E. Ehrlich, L. Faltan, M. Illner (eds.). 2001. Central Europe in Transition: Towards EU Membership. Warsaw: Scholar Publishing House.

Granato, J., R. Inglehart, D. Leblang. 1996. „The Effect of Cultural Values in Economic Development: Tudory, Hypothese and Some Empirical Tests." American Journal of Political Science 40: 607-631.

Granovetter, M. 1973. „The Strength of Weak Ties.“ American Journal of Sociology 78 (6): 1360-1380.

Guiso, L., P. Sapienza, L. Zingales. 2004. „The Role of Social Capital in Financial Development." The American Economic Review 93 (4): 526-556.

Habermas, J. 1989. The Structural Transformation of the Public Sphere: An Incquiry into a Category of Bourgeois Society. Cambridge: MIT Press.

Hadjimichilis, C. 2007. „Non-Economic Factors in Economic Geography and in ,New Regionalism': A Symphatetic Critique." International Journal of Urban and Regional Research 31 (1): 245-252.

Hall, P. 1999. „Social Capital in Britain.“ British Journal of Political Science 29: 417-461.

Halpern, D. S. 2005. Social Capital. Cambridge: Polity.

Hampl, M. 1971. Teorie komplexity a diferenciace světa. Praha: Univerzita Karlova.

Hampl, M. 2007. „Regionální diferenciace současného socioekonomického vývoje v České republice." Sociologický časopis / Czech Sociological Review 43 (5): 889-910.

Harrison, L. E., S. P. Huntington (eds.). 2000. Culture Matters: How Values Shape Human Progress. New York: Basic Books.

Helliwell, J., R. Putnam. 1995. „Economic Growth and Social Capital in Italy.“ Eastern Economic Journal 11: 295-307.

Helliwell, J., R. Putnam. 2000. „Economic growth and social capital in Italy.“ Pp. 253-266 in P. Dasgupta, I. Seragilden (eds.). Capital: A Multifaceted Perspective. Washington, D.C.: World Bank.

Hospers, G. J., M. van Lochem. 2002. „Social Capital and Prosperity.“ New Economy 9 (1): 52-56.

Illner. M. 2006. „La République Tchèque. Le débat émergent de la gouvernance.“ Pp. 183-196 in G. Marcou, H. Wollmann (eds.). Annuaire 2006 des collectivites locales. Paris: CNRS Editions.

Illner, M., Z. Vajdová. 2006. El govern territorial a la República Txeca després de la transformació del sistema. Barcelona: Istitut d'Edicions de la Diputació de Barcelona.

Illner, M., T. Kostelecký, V. Patočková. 2007. „Jak fungují kraje - příspěvek k hodnocení výkonu krajských vlád." Sociologický časopis / Czech Sociological Review 43 (5): 911-943.

Jacobs, J. 1961. Death and Life of Great American Cities. New York: Modern Library.

Jehlička, P., J. Tomeš, P. Daněk. 2000. Stát, prostor, politika. Vybrané otázky politické geografie. Praha: Přírodovědecká fakulta Univerzity Karlovy.

Johnston, R. J., C. J. Pattie, J. G. Allsopp. 1988. A Nation Dividing? London: Longman Group.

Kaufman, J., S. J. Tepper. 1999. „Groups or Gatherings? Sources of Political Engagement in 19th Century American Cities." Voluntas: International Journal of Voluntary and Nonprofit Organizations 10 (4): 299-322.

Knack, S. 2002. "Social Capital and the Duality of Government: Evidence From the 
States." American Journal of Political Science 46 (4): 772-785.

Koreleski D. 2005. „Socio-economic Regional Diferences in Poland.“ Wies i Rolnictwo 4 (129): 155-164.

Kostelecký, T. 1993. Geografické analýzy volebních výsledků jako součást politické geografie. Dizertační práce. Praha: Karlova univerzita.

Kostelecký, T. 1995. Politické, ekonomické a sociální aspekty chování obyvatel České republiky v období postkomunistické tranformace společnosti - regionální perspektiva. Working Papers SOÚ AV ČR 95:5. Praha: Sociologický ústav AV ČR.

Kostelecký, T. 2001. Vzestup nebo pád politického regionalismu? Working Papers SOÚ AV ČR 01:9. Praha: Sociologický ústav AV ČR.

Kostelecký, T. 2002. „Vývoj české společnosti v devadesátých letech 20. století v regionálním pohledu." Pp. 3-29 in T. Kostelecký, J. Stachová, D. Čermák. Region a politika. Sociologické texty / Sociological Papers 02:7. Praha: Sociologický ústav AV ČR.

Kostelecký, T. 2005: „Public Administration, Regional Policy, and the Committee of the Regions - Interaction of Regional, National and European Influences in the Preaccession Czech Republic." NISPAcee Occasional Papers in Public Administration and Public Policy 6 (1): 14-34.

Kostelecký, T., J. Vobecká (eds.). 2005. Regionální elity 2004. Sociologické studie / Sociological Studies 05:03. Praha: Sociologický ústav AV ČR.

Kostelecký, T., V. Patočková. 2006. „Fungování národních, regionálních a lokálních vlád - problém měření výkonu vlád („government performance“)." Sociologický časopis / Czech Sociological Review 42 (5): 913-936.

Krivý, V., V. Feglová, D. Balko. 1996. Slovensko a jeho regiony. Bratislava: Nadácia Médiá.

Langton, J., R. J. Morris. 1986. Atlas of of Industrializing Britain, 1780-1914. New York: Metheun.

Lemann, N. 1996. „Kicking in groups.“ The Atlantic Monthly 277 (4): 22-26.

Leonardi, R., R. Y. Nanetti (eds.). 1990. The Regions and European Intergation. London, New York: Pinter Publishers.

Leonardi, R. 1993. The Regions and the European Community: The Regional Response to the Single Market in the Underdeveloped Areas of the EC. London: Frank Cass.

Levy, J. 1999. Tocqueville's Revenge. Cambridge, Mass.: Harvard University Press.

Lipset, M. 1960. Political man; the social bases of politics. Garden City: Doubleday.

Martinussen, P. E. 2004. „Government Performance and Political Accountability at Subnational Level: The Electoral Fate of Local Incumbents in Norway." Scandinavian Political Studies 27 (3): 227-259.

Marx, K. 1867. Das Kapital. Hamburg: Verlag von Otto Meissner.

Mayer, P. B. 2001. „Human Development and Civic Community in India. Making Democracy Perform." Economic and Political Weekly, February 24: 684-692.

McLaren, L. M., V. A. Baird. 2006. „Of Time and Causality: A Simple Test of the Requirement of Social Capital in Making Democracy Work in Italy." Political Studies 54 (4): 889-897.

Milner, H., S. Ersson. 2000. „Social Capital, Civic Engagement and Institutional Performance in Sweden: An Analysis of the Swedish Regions." Paper presented at ECPR Joint Sessions of Workshop. University of Copenhagen, 14.-19. 4. 2000.

Mohan, G., Mohan, J. 2002. „Placing social capital.“ Progress in Human Geography 26 (2): 191-210.

Myant, M., S. Smith. 2006. „Regional Development and Post-Communist Politics in a Czech Region." Europe-Asia Studies 58 (2): 147-168.

Myrdal, G. 1957. Economic theory and under-developed regions. London: G. Duckworth.

OECD. 2001. Cities and Regions in the New Learning Economy. Paris: OECD. 
Ostrom, E. 1990. Governing the Commons: the Evolution of Institutions for Collective Action. Cambridge: Cambridge University Press.

Olson, M. 1982. The Rise and Decline of Nations: Economic Growth, Stagflation, and Social Rigidities. New Haven, Conn.: Yale University Press.

Pavlínek, P. 1997. Economic Restructuring and Local Environmental Management. New York: The Edwin Mellen Press.

Paxton, P. 1998. „Is social capital declining in the United States? A multiple indicator assessment." American Journal of Sociology 105 (1): 88-127.

Paxton, P. 2006. „Social Capital and Democracy: An Interdependent Relationship.“ American Sociological Review 67: 254-277.

Polèse, M., R. Shearmur. 2006. „Why some regions will decline: A Canadian case study with thought on local development strategie." Papers in Regional Science 85 (1): 23-46.

Portes, A. 2000. „The two meanings of social capital.“ Sociological Forum 15: 1-12.

Portes, A., P. Landolt. 2000. „Social capital: promise and pitfalls of its role in the development." Journal of Latin American Studies 32: 529-547.

Putnam, R. D., R. Leonardi, R. Y. Nanetti. 1993. Making Democracy Work. Civic Traditions in Modern Italy. Princeton: Princeton University Press.

Putnam, R. D. 1995, „Bowling Alone: America's Declining Social Cupital.“ Journal of Democracy 6 (1): 65-78.

Putnam, R. D. 2000. Bowling Alone: The Collapse and Revival of American Community. New York: Simon \& Schuster.

Putzel, J. 1997. „Accounting for the ,dark side' of social capital: reading Robert Putnam on democracy." Journal of International Development 9 (7): 939-949.

Rae, D. W. 1971. The Political Consequences of Electoral Laws. New Haven: Yale University Press.

Ratzel, F. 1897. Politische geographie. München: R. Oldenbourg.

Reilly, B., R. Phillpot. 2002. ",'Making Democracy Work' in Papua New Guinea: Social Capital and provincial Development in an Ethnically Fragmented Society." Asian Survey 42 (6): 906-927.

Rice, T. W., A. F. Sumberg. 1997. "Civic culture and government performance in the American states." Publius: The Journal of Federalism 27 (1): 99-114.

Schneider, G., T. Plümper, S. Baumann. 2000. „Bringing Putnam to the European Regions." European Urban and Regional Studies 7 (4): 307-317.

Smith, A. 1776. An Inquiry into the Nature and Causes of the Wealth of Nations. Dublin: Whitestone.

Stachová, J. 2005. Občanská společnost v regionech v České republice. Sociologické studie / Sociological Studies 05:06. Praha: Sociologický ústav AV ČR.

Tarrow, S. 1996. „Making social science work across space and time: a critical reflection on Robert Putnam's Making democracy work." American Political Science Review 90 (2): 389-397.

Taylor, P. J. 1985. Political Geography. World Economy, Nation State and Locality. London: Longman.

Tocqueville, A. de. 1835. De la dèmocratie en Amèrique. Bruxelles: L. Hauman et Cie.

Tomeš, J., Hampl, M. 1999. „The Development of Regional Differentiation in Eastern Central European Countries during the Transformation Era." Pp. 131-151 in Martin Hampl et al. Geography of Societal Transformation in the Czech Republic. Praha: Př́rodovědecká fakulta UK.

Tworzecki, H. 1996. Parties and Politics in Post-1989 Poland. Boulder: Westview Press.

Uslaner, E. M. 2000. „Producing and Consuming Trust.“ Political Science Quarterly 115 (4): 569-590. 
Vajdová, Z., T. Kostelecký. 1997. „Politická kultura lokálních společenství: případ tří měst." Sociologický časopis 33: 457-469.

Wallerstein, I. 1980. The Modern World-System I: Capitalist Agriculture and the Origins of the European World-Economy in the Sixteenth Century. New York: Academic Press.

Weber, M. 1904-1905. „Die protestantische Ethik und der Geist des Kapitalismus.“ Archiv für Sozialwissenschaften und Sozialpolitik 20: 1-54, 21: 1-110.

World Development Indicators 2007. Washington, D.C.: International Bank for Reconstruction and Development / the World Bank.

Zarycki, T. 2000. „Politics in the Periphery: the Interpretation of Political Cleavages in Poland in their Historical and International Context." Europe-Asia Studies 52 (5): 851-873.

Zarycki, T. 2007. „History and Regional Development. A Controversy over the "Right” Interpretation of the Role of History in the Development of the Polish Regions." GeoForum 38: 485-493. 


\section{Př́loha 1. Přehled indikátorů použitých v článku a zdroje dat}

Ukazatele ekonomického rozvoje

- HDP na obyvatele 1995, 2004, ČR = $100 \%$

- HDP na zaměstnance 1995, 2004, ČR = 100\%

- Čistý disponibilní důchod domácnosti na 1 obyvatele 1995, 2004, v Kč

- Registrovaná míra nezaměstnanosti 1995, 2005, ČR = 100\%

Zdroj: ČSÚ, Statistické ukazatele charakterizující ČR a její regionální strukturu. Praha. Př́loha č. 4 ke Strategii regionálního rozvoje ČR.

- Fyzické osoby - podnikatelé registrovaní k platbě DPH na konci roku, 1995, 2005

Zdroj: Čsú, data na vyžádání.

Ukazatele úrovně sociálního kapitálu

- Počet nestátních neziskových organizací, 2004

Zdroj: ČSÚ, data na vyžádání.

- Čtenost regionálních, celostátních novin a sledovanost TV zpráv, 2006, \% populace

Zdroj: Media projekt, Sběr dat: 3.Q roku 2006.

- Důvěra prezidentovi, krajským a obecním zastupitelstvům, 2004, \% populace Zdroj: CVVM, šetření "Naše společnost" - prüměrné údaje za rok 2004.

- Počet dobrovolných dárců krve, 2004

Zdroj: ÚZIS ČR. Činnost zdravotnických zařizení ve vybraných oborech léěebně preventivní péče 2004. Praha: ÚZIS ČR.

- Účast ve volbách do Poslanecké sněmovny Parlamentu ČR, 1998, 2002, 2006, \% voličů

- Účast ve volbách do krajských zastupitelstev, 2000, 2004, \% voličů

- Účast v referendu o vstupu ČR do Evropské unie 2003, \% voličů

Zdroj: ČSÚ, volební server www.volby.cz. 
Ukazatele výkonu krajských vlád

Podrobný popis viz článek Illner et al. [2007] v tomto čísle Sociologického časopisu.

Kontrolní proměnné

- Podíl osob ve věku 25-34 let s úplným středoškolským a vyšším vzděláním na 100 obyvatel

- Podíl osob ve věku 15 a více s úplným SŠ vzděláním nebo vyšším na 100 obyvatel

- Podíl osob ve věku 25-34 let s úplným vysokoškolským vzděláním na 100 obyvatel

- Podíl osob ve věku 25 a více s úplným vysokoškolským vzděláním na 100 obyvatel

- Podíl věřících na 100 obyvatel

Zdroj: vlastní výpočty z dat ČSÚ SLDB 2001.

- Výsledky voleb do krajských zastupitelstev 2000, 2004, \% hlasů pro jednotlivé strany

- Výsledky voleb do krajských zastupitelstev 2000, 2004, \% mandátů pro jednotlivé strany

- Výsledky voleb do krajských zastupitelstev 2000, 2004, počet radních za jednotlivé strany

Zdroj: [Balík, Koloušek 2005].

- Rozvojový optimismus krajských polit. a administrativních elit - rozvojové možnosti kraje, 2004, \% respondentů hodnotících možnosti jako dobré

Zdroj: Sociologický ústav AV ČR. Regionální elity 2004 - vlastní šetření. 